\title{
Supplemental Reference List for the National Water Summary on Wetland Resources
}

Compiled By: Kimberly L. Fry, U.S. Geological Survey

U.S. GEOLOGICAL SURVEY

Open-File Report 96-169

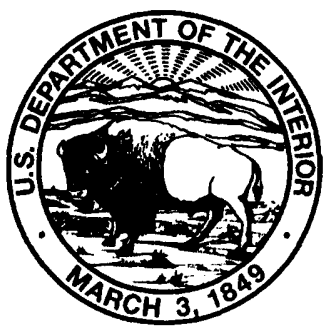




\title{
U.S. DEPARTMENT OF THE INTERIOR BRUCE BABBITT, Secretary
}

\author{
U.S. GEOLOGICAL SURVEY
}

Gordon P. Eaton, Director

The use of firm, trade, and brand names in this report is for identification purposes only and does not constitute endorsement by the U.S. Geological Survey.

Copies of this report can be purchased from:

U.S. Geological Survey Information Services

Box 25286

Federal Center

Denver, CO 80225 


\section{CONTENTS}

\section{References for:}

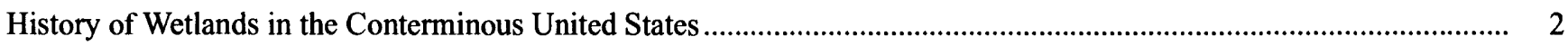

Wetland Definitions and Classifications in the United States....................................................................................

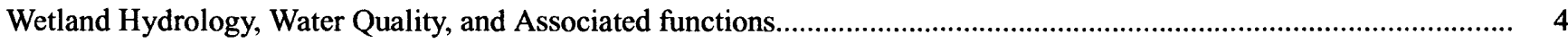

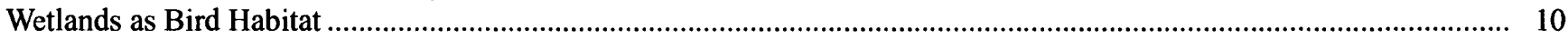

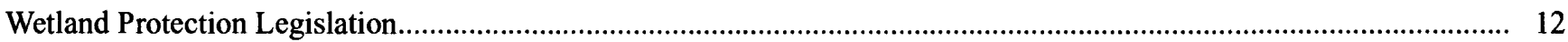

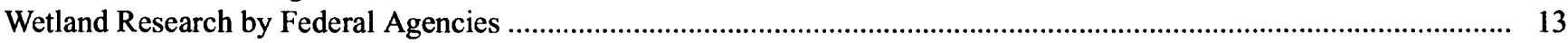

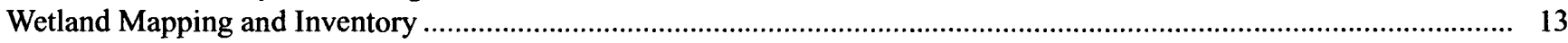

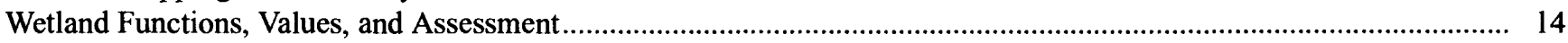

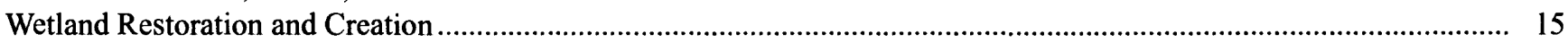

Effects of Hurricane Andrew (1992) on Wetlands in southern Florida and Louisiana ................................................ 17

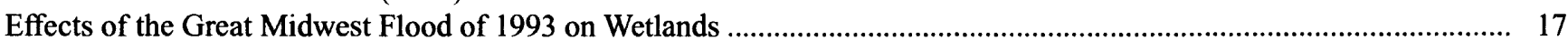




\title{
UIS SUPPLEMENTAL REFERENCE LIST GIS FOR THE NATIONAL WATER SUMMARY ON WETLAND RESOURCES
}

Compiled by Kimberley L. Fry ${ }^{1}$

\begin{abstract}
References following each article in the "Overview of Wetland Resources" section of the "National Water Summary on Wetland Resources" (U.S. Geological Survey Water-Supply Paper 2425) were limited to those cited in the text. However, the authors felt strongly that a more extensive list would benefit those readers who wished to go into more depth on specific topics. Following is an extended list of references for topics addressed in the National Water Summary. The references are presented in lists by topic that parallel their order of presentation in the National Water Summary. Topics (with contributing authors listed) are ordered as follows:
\end{abstract}

History of Wetlands in the Conterminous United States

Thomas E. Dahl and Gregory J. Allord

Wetland Definitions and Classifications in the United States

Ralph W. Tiner

Wetland Hydrology, Water Quality, and Associated Functions

Virginia Carter

Wetlands as Bird Habitat

Robert E. Stewart, Jr.

Wetland Protection Legislation

Todd H. Votteler and Thomas A. Muir

Wetland Research by Federal Agencies

Richard E. Coleman, Edward T. LaRoe, and Russell F. Theriot

Wetland Mapping and Inventory

Bill $O$. Wilen, Virginia Carter, and J. Ronald Jones

Wetland Functions, Values, and Assessment

Richard P. Novitzki, R. Daniel Smith, and Judy D. Fretwell

Wetland Restoration and Creation

Mary E. Kentula

Effects of Hurricane Andrew (1992) on Wetlands in Southern Florida and Louisiana

John K. Lovelace and Benjamin J. McPherson

Effects of the Great Midwest Flood of 1993 on Wetlands

James R. Kolva

\footnotetext{
' U.S. Geological Survey
} 
History of Wetlands in the Conterminous

United States

Beauchamp, K.H., 1987, A history of drainage and drainage methods, in Pavelis, G.A., ed., Farm drainage in the United States-history, status, and prospects: Washington, D.C., Economic Research Service, U.S. Department of Agriculture Miscellaneous Publication 1455, p. 13-29.

Bednarik, K.E., 1984, Saga of the Lake Erie marshes, in Hawkins, A.S., Hanson, R.C., Nelson, H.K., and Reeves, H.M., eds., Flyways-pioneering waterfowl management in North America: Washington, D.C., U.S. Fish and Wildlife Service, p. 423-430.

Burwell, R.W., and Sugden, L.G., 1964, Potholes-going, going..., in Linduska, J.P., ed., Waterfowl tomorrow: Washington, D.C., U.S. Fish and Wildlife Service, p. 369-380.

Clarke, M.J., 1977, An economic and environmental assessment of the Florida Everglades sugarcane industry: Baltimore, Md., John Hopkins University, 140 p.

Dahl, T.E., 1990, Wetlands-losses in the United States, 1780's to 1980's: Washington, D.C., U.S. Fish and Wildlife Service Report to Congress, $13 \mathrm{p}$.

Dahl, T.E., and Johnson, C.E., 1991, Wetlands-status and trends in the conterminous United States-mid-1970's to mid-1980's: Washington, D.C., U.S. Fish and Wildlife Service,22 p.

Danhof, C.H., 1941, Farm-making costs and the safety valve1850-1860: Journal of Political Economy, v. 49, p. 317-359.

Dietrich, T.S., 1978, The urbanization of Florida's population: An historical perspective of county growth 1830-1970: Gainesville, Fla., Bureau of Economic and Business Research, University of Florida, $211 \mathrm{p}$.

Erickson, R.E., 1979, Federal programs influencing wetlands, in Michigan Landuse Policy Conference, 7th, East Lansing, Mich., 1979, Michigan State University, 246 p.

Erickson, R.E., Linder, R.L., and Harmon, K.W., 1979, Stream channelization (p.l. 83-566) increased wetland losses in the Dakotas: Wildlife Society Bulletin, v. 7, no. 2, p. 71-78.

Eyre, F.H., 1980, Forest cover types of the United States and Canada: Washington, D.C., Society of American Foresters, $148 \mathrm{p}$.

Frayer, W.E., Monahan, T.J., Bowden, D.C., and Graybill, F.A., 1983, Status and trends of wetlands and deepwater habitats in the conterminous United States, 1950's to 1970's: Fort Collins, Colo., Colorado State University, 32 p.

Frayer, W.E., Peters, D.D., and Pywell, H.R., 1989, Wetlands of the California Central Valley - status and trends-1939 to mid-1980's: Portland, Oreg., U.S. Fish and Wildlife Service, $28 \mathrm{p}$.

Freeman, A.E., and Bussewitz, W.R., 1948, History of Horicon: Horicon, Wis., $126 \mathrm{p}$.

Garrett, W.E., ed., 1988, Historical atlas of the United States: Washington, D.C., National Geographic Society, 289 p.

Glaser, P.H., 1987, The ecology of patterned boreal peatlands of northern Minnesota-a community profile: U.S. Fish and Wildlife Service Biological Report 85(7.14), 98 p.

Gordon, R.B., 1969, The natural vegetation of Ohio in pioneer days: Columbus, Ohio, Ohio State University, Bulletin of the Ohio Biological Survey, v. III, no. 2, 113 p.

Green, W.E., 1984, The great river refuge, in Hawkins, A.S., Hanson, R.C., Nelson, H.K., and Reeves, H.M., eds., Flyways-pioneering waterfowl management in North America: Washington, D.C., U.S. Fish and Wildlife Service, p. 431-439.

Howe, Henry, 1900, Historical collections of Ohio: Cincinnati, Ohio, Ohio centennial edition Published by the State of Ohio, v. 1,881 p.
Hundley, Norris, Jr., 1992, The great thirst-Californians and water 1700's-1990's: Berkeley, Calif., University of California Press, $551 \mathrm{p}$.

Johnson, C.D., 1976, Wetland use in Wisconsin-historical perspective and present picture: Madison, Wis., Wisconsin Department of Natural Resources, $46 \mathrm{p}$.

Knue, Joseph, 1988, Of time and prairie-100 years of people and wildlife in North Dakota - observations in change: Bismarck, N. Dak., North Dakota State Game and Fish Department, $106 \mathrm{p}$.

Light, S.S., and Dineen, J.W., 1994, Water control in the Everglades-a historical perspective, in Davis, S.M., and Ogden, J.C., eds., Everglades-the ecosystem and its restoration: Delray Beach, Fla., St. Lucie Press, p. 47-84.

Lord, L.A., 1993, Guide to Florida environmental issues and information: Winter Park, Fla., Florida Conservation Foundation, $364 \mathrm{p}$.

McManis, D.R., 1964, The initial evaluation and utilization of the Illinois prairies, 1815-1840: Chicago, Ill., University of Chicago, Department of Geography Research Paper 94, 109 p.

McNall, N.A., 1952, An agricultural history of the Genesee Valley, 1790-1860: Philadelphia, Pa., University of Pennsylvania Press, $276 \mathrm{p}$.

Middleton, E.P., 1917, History of Champaign County, Ohio, its people, industries and institutions: Indianapolis, Ind., B.E. Bowen and Co., Inc., $116 \mathrm{p}$.

Muehrcke, P.C., and Muehrcke, J.O., 1992, Map use: Madison, Wis., JP Publications, $631 \mathrm{p}$.

Office of Technology Assessment, 1984, Wetlands-their use and regulation: Washington, D.C., U.S. Congress, OTA-0-206, $208 \mathrm{p}$.

Ohio Department of Natural Resources, 1988, Ohio wetlands priority conservation plan —an addendum to the 1986 Ohio statewide comprehensive outdoor recreation plan: Columbus, Ohio, Ohio Department of Natural Resources, 67 p.

Pavelis, G.A., ed., 1987, Farm drainage in the United Stateshistory, status, and prospects: Economic Research Service, U.S. Department of Agriculture Miscellaneous Publication $1455,170 \mathrm{p}$.

Pickels, G.W., 1925, Drainage and flood control engineering: New York, McGraw-Hill, 450 p.

Ross, E.D., 1956, Retardation in farm technology before the power age: Agricultural History, v. 30, p. 11-18.

Schrader, T.A., 1955, Waterfowl and the potholes of the northcentral States, in The yearbook of agriculture, 1955: Washington, D.C., U.S. Department of Agriculture, 84th Congress, 1st session, House Document 32, p. 596-604.

Shaw, S.P., and Fredine, C.G., 1956, Wetlands of the United States - their extent and their value to waterfowl and other wildlife: U.S. Fish and Wildlife Service Circular 39, 67 p.

Stover, J.F., 1961, American railroads: Chicago, Ill., University of Chicago Press, $310 \mathrm{p}$.

Tant, P.L., 1981, Soil survey of Washington County, North Carolina: Washington, D.C., U.S. Soil Conservation Service, 99 p. and map sheets.

Tebeau, C.W., 1980, A history of Florida: Coral Gables, Fla., University of Miami Press, $527 \mathrm{p}$.

Trowell, C.T., 1988, Exploring the Okefenokee-Harper, Roland M., in The Okefenokee Swamp, 1902 and 1919: Douglas, Ga., North Georgia College, Research Paper 2, 89 p.

U.S. Bureau of the Census, 1832, Return of the whole number of persons within the several districts of the U.S., 1830: Washington D.C.

U.S. Fish and Wildlife Service, 1991, U.S. Department of the In- 
terior budget justification-fiscal year 1992: Washington, D.C, $121 \mathrm{p}$.

No date, Mattamuskeet National Wildlife Refuge: Swan Quarter, N.C. [brochure].

U.S. Geological Survey, 1970, National atlas of the United States of America: Washington, D.C., 140 p.

Washington County Historical Society, 1979, Historic Washington County: Plymouth, N.C., 31 p.

Wilford, J.N., 1981, The mapmakers: New York, Alfred A. Knopf, 414 p.

Wisconsin Department of Natural Resources, 1990, Wetlands/ wonderlands-Wisconsin natural resources: Madison, Wis., Wisconsin Department of Natural Resources, $16 \mathrm{p}$.

Wooten, H.H., and Jones, L.A., 1955, The history of our drainage enterprises, in The yearbook of agriculture, 1955: Washington, D.C., U.S. Department of Agriculture, 84th Congress, 1 st session, House Document 32, p. 478-498.

Wright, H.E., Jr., 1984, Red Lake peatland-its past and patterns: Minneapolis, Minn., University of Minnesota, James Ford Bell Museum of Natural History, v. 1, 7 p.

\section{Wetland Definitions and Classifications in the United States}

Akins, G.J., and Jefferson, C.A., 1975, Coastal wetlands of Oregon-a natural resource inventory report to the Oregon Coastal Conservation and Development Commission: Florence, Oreg., Oregon Coastal Conservation and Development Commission, $190 \mathrm{p}$.

Anderson, J.F., Hardy, E.E., and Roach, J.T., 1972, A land use classification system for use with remote sensor data: U.S. Geological Survey Circular 671, 16 p.

Anderson, J.F., Hardy, E.E., Roach, J.T., and Whitman, R.E., 1976, A land use and land cover classification system for use with remote sensor data: U.S. Geological Survey Professional Paper 964, 28 p.

Braun, E.L., 1950, Deciduous forests of eastern North America: New York, Hafner Publishing Co., 596 p.

Chabreck, R.H., 1972, Vegetation, water and soil characteristics of the Louisiana coastal region: Baton Rouge, La., Louisiana State University Agricultural Experiment Station Bulletin 664, $72 \mathrm{p}$.

Chapman, V.J., 1974, Salt marshes and salt deserts of the world (2d ed.): LeHre, Germany, J. Cramer, 392 p.

1976, Coastal vegetation (2d ed.): Oxford, England, Pergaman Press, 292 p.

Cowardin, L.M., Carter, Virginia, Golet, F.C., and LaRoe, E.T., 1976, Interim classification of wetland and aquatic habitats of the United States: Washington, D.C., U.S. Fish and Wildlife Service, Office of Biological Services, $110 \mathrm{p}$.

1977, Classification of wetlands and deepwater habitats of the United States: U.S. Fish and Wildlife Service, 100 p.

1979, Classification of wetlands and deepwater habitats of the United States: U.S. Fish and Wildlife Service, Biological Services Program Report FWS/OBS-79/31, 131 p.

Curtis, J.T., 1959, The vegetation of Wisconsin: Madison, Wis., University of Wisconsin Press, 657 p.

Dachnowski, A.P., 1920, Peat deposits in the United States and their classification: Soil Science, v. 10, no. 6, p. 453-456.

Dansereau, Pierre, and Segadas-Vianna, Fernando, 1952, Ecological study of peat bogs of eastern North America, Istructure and evolution of vegetation: Canadian Journal of Botany, v. 30, p. 490-518.

Dix, R.L., and Smeins, F.E., 1967, The prairie, meadow and marsh vegetation of Nelson County, North Dakota: Canadian Journal of Botany, v. 45, p. 21-58.

Eleuterius, L.M., 1972, The marshes of Mississippi: Castanea, v. 37, p. 153-168.

Federal Interagency Committee for Wetland Delineation, 1989, Federal manual for identifying and delineating jurisdictional wetlands: Washington, D.C., U.S. Army Corps of Engineers, Environmental Protection Agency, Fish and Wildlife Service, and Soil Conservation Service, 76 p. plus appendixes.

Golet, F.C., and Larson, J.S., 1974, Classification of freshwater wetlands in the glaciated Northeast: U.S. Fish and Wildlife Service Resource Publication 116, 56 p.

Gopal, Brij, Turner, R.E., Wetzel, R.G., and Whigham, D.F., 1982, Wetlands ecology and management, in International Wetlands Conference, 1st, New Delhi, India, September 1017, 1980, Proceedings: Jaipur, India, National Institute of Ecology and International Scientific Publications, 514 p.

Heinselman, M.L., 1963, Forest sites, bog processes, and peatland types in the glacial Lake Agassiz region, Minnesota: Ecological Monographs, v. 33, p. 327-374.

1970, Landscape evolution, peatland types, and the environment in the Lake Agassiz Peatlands Natural Area, Minnesota: Ecological Monographs, v. 40, p. 235-261.

Jeglum, J.K., 1971, Plant indicators of pH and water level in peatlands at Candle Lake, Saskatchewan: Canadian Journal of Botany, v. 49, no. 9, p. 1661-676.

Kuenzler, E.J., 1974, Mangrove swamp systems, v. 1 of Odum, H.T., Copeland, B.M., and McMahan, E.A., eds., Coastal ecological systems of the United States: Washington, D.C., The Conservation Foundation, p. 346-371.

Larson, J.S., Bedinger, M.S., Bryan, C.F., and others, 1981, Transition from wetlands to uplands in southeastern bottomland hardwood forests, in Clark, J.R., and Benforado, Jay, eds., Wetlands of bottomland hardwood forests: Amsterdam, Elsevier Science Publishers, p. 225-275.

Lefor, M.W., and Kennard, W.C., 1977, Inland wetland definitions: Storrs, Conn., University of Connecticut, Institute of Water Resources Report 28, 63 p.

Leitch, W.G., 1966, Historical and ecological factors in wetland inventory: North American Wildlife and Natural Resources Conference 31, Transactions, p. 88-96.

Mader, S.F., 1991, Forested wetlands classification and mapping-a literature review: New York, National Council of the Paper Industry for Air and Stream Improvement, Inc., Technical Bulletin 606, 99 p.

Martin, A.C., Hotchkiss, Neil, Uhler, F.M., and Bourn, W.S., 1953, Classification of wetlands of the United States: Washington D.C., U.S. Fish and Wildlife Service Special Scientific Report, Wildlife, no. 20, 14 p.

Mitsch, W.J., and Gosselink, J.G., 1986, Wetlands: New York, Van Nostrand Reinhold, 539 p.

National Research Council, Committee on Characterization of Wetlands, 1995, Wetlands- characteristics and boundaries: Washington, D.C., National Academy Press, 268 p.

Niering, W.A., 1984, Wetlands: New York, Alfred A. Knopf, Inc., $638 \mathrm{p}$.

Penfound, W.T., 1952, Southern swamps and marshes: Botanical Review, v. 18, p. 413-446.

Pestrong, Raymond, 1965, The development of drainage patterns on tidal marshes: Stanford, Calif., Stanford University Publications in the Geological Sciences, v. 10,110 p.

Redfield, A.C., 1972, Development of a New England salt marsh: Ecological Monographs, v. 42, p. 201-237.

Reed, P.B., Jr., 1988, National list of plant species that occur in 
wetlands-1988 national summary: U.S. Fish and Wildlife Service Biological Report 88(24), 244 p.

Remane, Adolfe, and Schlieper, Carl, 1971, Biology of brackish water: New York, John Wiley, 372 p.

Sather, J.H., ed., 1976, National wetland classification and inventory workshop, College Park, Md., July 20-23, 1975, Proceedings: Washington, D.C., U.S. Fish and Wildlife Service Report, 358 p.

Scott, M.L., Slauson, W.L., Segelquist, C.A., and Auble, G.T., 1989 , Correspondence between vegetation and soils in wetlands and nearby uplands: Wetlands, v. 9, no. 1, p. 41-60.

Segelquist, C.A., Slauson, W.L., Scott, M.S., and Auble, G.T., 1990, Synthesis of soil-plant correspondence data from twelve wetland studies throughout the United States: U.S. Fish and Wildlife Service Biological Report 90(19), 24 p.

Shaw, S.P., and Fredine, C.G., 1956, Wetlands of the United States-their extent, and their value to waterfowl and other wildlife: U.S. Fish and Wildlife Service Circular 39, 67 p.

Sjors, Hugo, 1950, On the relation between vegetation and electrolytes in north Swedish mire waters: Oikos, v. 2, p. 241-258.

Stewart, R.E., and Kantrud, H.A., 1971, Classification of natural ponds and lakes in the glaciated prairie region: U.S. Fish and Wildlife Service Resource Publication 92, 57 p.

Tiner, R.W., 1984, Wetlands of the United States-current status and recent trends: Washington, D.C., U.S. Fish and Wildlife Service Report, 59 p.

1987, A field guide to coastal wetland plants of the northeastern United States: Amherst, Mass., University of Massachusetts Press, 285 p.

1989, Wetland boundary delineation, in Majumdar, S.K., Brooks, R.P., Brenner, F.J., and Tiner, R.W., Jr., eds., Wetlands ecology and conservation-emphasis in Pennsylvania: Philadelphia, Pa., Pennsylvania Academy of Science, p. 231-248.

1991 , The concept of a hydrophyte for wetland identification: BioScience, v. 41, no. 4, p. 236-247.

1993a, Field guide to coastal wetland plants of the southeastern United States: Amherst, Mass., University of Massachusetts Press, $328 \mathrm{p}$.

1993b, Using plants as indicators of wetland: Academy of Natural Sciences of Philadelphia, Proceedings, v. 144, p. 240-253.

U.S. Fish and Wildlife Service, 1976, Existing State and local wetland surveys (1965-1975), v. II, Narrative: Washington, D.C., U.S. Fish and Wildlife Service, Office of Biological Services Report, 453 p.

U.S. Soil Conservation Service, 1991, Hydric soils of the United States: U.S. Soil Conservation Service, Miscellaneous Publication 1491, unnumbered pages.

Veneman, P.L.M., and Tiner, R.W., 1990, Soil-vegetation correlations in the Connecticut River floodplain of western Massachusetts: Washington, D.C., U.S. Fish and Wildlife Service Biological Report 90(6), 51 p.

Wilen, B.O., and Tiner, R.W., 1993, Wetlands of the United States, in Whigham, D.F., Dykyjová, Dagmar, and Hejny, Slavomil, eds., Wetlands of the world, I: Dordrecht, The Netherlands, Kluwer Academic Publishers, p. 515-636.

Wright, J.O., 1907, Swamp and overflowed lands in the United States: Washington, D.C., U.S. Department of Agriculture, Office of Experiment Stations, Circular 76, 23 p.

Wetland Hydrology, Water Quality, and Associated Functions

Adamus, P.R., Stockwell, L.T., Clairain, E.J., Jr., Morrow, M.E., Lawrence, P.R., and Smith, R.D., 1991, Wetland Evaluation
Technique (WET); v. 1, Literature review and evaluation rationale: U.S. Army Corps of Engineers, Wetlands Research Program Technical Report WRP-DE-2, 287 p.

Arndt, J.L., and Richardson, J.L., 1989, Geochemistry of hydric soil salinity in a recharge-throughflow-discharge prairie-pothole wetland system: Soil Science Society of America Journal, v. 53 , p. $848-855$.

Bedinger, M.S., 1981, Hydrology of bottomland hardwood forests of the Mississippi embayment, in Clark, J.R., and Benforado, Jay, eds., Wetlands of bottomland hardwood forests: Federal Highway Administration Report FHWA-TS84-204, p. 1-62.

Belanger, T.V., Scheidt, D.J., and Platho, J.R., 1989, Effects of nutrient enrichment on the Florida Everglades: Lake and Reservoir Management, v. 5, no. 1, p. 101-111.

Boelter, D.H., and Verry, E.S., 1977, Peatland and water in the northern lake States: Forest Service General Technical Report $\mathrm{NC}-31,22 \mathrm{p}$.

Bokuniewicz, Henry, and Pavlik, Barbara, 1990, Groundwater seepage along a barrier island: Biogeochemistry, v. 10, p. 257-276.

Boyt, F.L., Bayley, S.E., and Zoltek, John, Jr., 1977, Removal of nutrients from treated municipal wastewater by wetland vegetation: Water Pollution Control Federation Journal, v. 49, no. 5, p. 789-799.

Bricker-Urso, Suzanne, Nixon, S.W., Cochran, J.K., Hirschberg, D.J., and Hunt, C.D., 1989, Accretion rates and sediment accumulation in Rhode Island salt marshes: Estuaries, v. 12, no. 4, p. 300-317.

Brinson, M.M., 1988, Strategies for assessing the cumulative effects of wetland alteration on water quality: Environmental Management, v.12, no. 5, p. 655-662.

1993, A hydrogeomorphic classification for wetlands: U.S. Army Corps of Engineers Technical Report WRP-DE4, $79 \mathrm{p}$.

Brown, Jerry, Dingman, S.L., and Lewellen, R.I., 1968, Hydrology of a drainage basin on the Alaskan coastal plain: Hanover, N.H., U.S. Army Corps of Engineers, Cold Regions Research and Engineering Laboratory Research Report 240, $18 \mathrm{p}$.

Brown, Jerry, Pitelka, F.A., and Coulombe, H.N., 1970, Structure and function of the tundra ecosystem at Barrow, Alaska, in Conference on Productivity and Conservation in Northern Circumpolar Lands, Edmonton, Alberta, Canada, 1969, Proceedings: Morges, Switzerland, International Union for the Conservation of Nature and Natural Resources, p. 41-71.

Brown, R.J.E., 1974, Distribution and environmental relationships of permafrost: Canada National Committee for the Hydrologic Decade, p. 1-5.

Carter, Virginia, 1986, An overview of the hydrologic concerns related to wetlands in the United States: Canadian Journal of Botany, v. 64, no. 2, p. 364-374.

Carter, Virginia, Bedinger, M.S., Novitzki, R.P., and Wilen, W.O., 1979, Water resources and wetlands, in Greeson, P.E., Clark, J.R., and Clark, J.E., eds., Wetland functions and values-the state of our understanding, National Symposium on Wetlands, Lake Buena Vista, Fla., 1978, Proceedings: Minneapolis, Minn., American Water Resources Association, p. 344-376.

Carter, Virginia, Gammon, P.T., and Garrett, M.K., 1994, Ecotone dynamics and boundary determination in the Great Dismal Swamp, Virginia and North Carolina: Ecological Applications, v. 4, p. 189-203.

Carter, Virginia, and Novitzki, R.P., 1988, Some comments on the relation between ground water and wetlands, in Hook, D.D., McKee, W.H., Jr., Smith, H.K., and others, eds., The ecology 
and management of wetlands; v. 1, The ecology of wetlands: Portland, Oreg., Timber Press, p. 68-86.

Chambers, R.M., Harvey, J.W., and Odum, W.E., 1992, Ammonium and phosphate dynamics in a Virginia salt marsh: Estuaries, v. 15 , no. 3 , p. 349-359.

Chason, D.B., and Siegel, D.I., 1986, Hydraulic conductivity and related physical properties of peat, Lost River Peatland, northern Minnesota: Soil Science, v. 142, no. 2, p. 91-99.

Chescheir, G.M., Gilliam, J.W., Skaggs, R.W., and Broadhead, R.G., 1991, Nutrient and sediment removal in forested wetlands receiving pumped agricultural drainage water: Wetlands, v. 2, no. 1, p. 87-103.

Choquette, A.F., 1988, Regionalization of peak discharges for streams in Kentucky:

U.S. Geological Survey Water-Resources Investigations Report $87-4209,105 \mathrm{p}$.

Church, Michael, 1974, Hydrology and permafrost with reference to northern North America: Conference on Permafrost Hydrology, Canada, 1974, Proceedings, p. 7-20.

Clark, J.R., and Benforado, Jay, 1981, Wetlands of bottomland hardwood forests, in Workshop on bottomland and hardwood forest wetlands of the United States, Lanier, Ga., 1980, proceedings: New York, Elsevier Science Publishers, 401 p.

Clymo, R.S., 1984, The limits to peat bog growth: Royal Society of London, Philosophical Transactions, series B, v. 303, p. 605-654.

Cowardin, L.M., Carter, Virginia, Golet, F.C., and LaRoe, E.T., 1979, Classification of wetlands and deepwater habitats of the United States: U.S. Fish and Wildlife Service, Biological Services Program Report FWS/OBS-79/31, 131 p.

Craighead, F.C., 1971, The trees of south Florida; v. I, The natural environments and their succession: Coral Gables, Fla., University of Maine Press, 212 p.

Damman, A.W.H., 1978, Distribution and movement of elements in ombrotrophic peat bogs: Oikos, v. 30, p. 480-495.

1990, Nutrient status of ombrotrophic peat bogs: Aquilo Series Botany, v. 28, p. 5-14.

Damman, A.W.H., and French, T.W., 1987, The ecology of peat bogs of the glaciated northeastern United States-a community profile: U.S. Fish and Wildlife Service Biological Report $85(7.16), 100 \mathrm{p}$.

Daniel, C.C., III, 1981, Hydrology, geology and soils of pocosins - a comparison of natural and altered systems, in Richardson, C.J., Matthews, M.L., and Anderson, S.A., eds., Pocosin wetlands: Stroudsbury, Pa., Hutchinson Ross Publishing Company, p. 69-108.

Davis, R.B., and Anderson, D.S., 1991, The eccentric bogs of Maine - a rare wetland type in the United States: University of Maine Technical Bulletin 146, $151 \mathrm{p}$.

Day, F.P., Jr., West, S.K., and Tupacz, E.G., 1988, The influence of ground-water dynamics in a periodically flooded ecosystem, the Great Dismal Swamp: Wetlands, v. 8, p. 1-13.

Day, J.W., Jr., Butler, T.J., and Conner, W.H., 1976, Productivity and nutrient export studies in a cypress swamp and lake system in Louisiana, in Georgia Department of Natural Resources Office of Planning and Research Resources Planning Section, Conference reports-the environmental impact of fresh water wetland alterations on coastal estuaries: Georgia Department of National Resources, p. 3-16.

Dean, R.G., 1979, Effects of vegetation on shoreline erosional processes, in Greeson, P.E., Clark, J.R., and Clark, J.E., eds., Wetland functions and values - the state of our understanding: National Symposium on Wetlands, Lake Buena Vista, Fla., 1978, Proceedings: Minneapolis, Minn., American Wa- ter Resources Association, p. 415-426.

Delaune, R.D., Lindau, C.W., Knox, R.S., and Smith, C.J., 1990, Fate of nitrogen and phosphorus entering a gulf coast freshwater lake-a case study: Water Resources Bulletin, v. 26, no. 4, p. 621-631.

Dingman, S.L., 1971, Hydrology of the Glenn Creek Watershed Tanana River Basin, central Alaska: Hanover, N.H., U.S. Army Corps of Engineers, Cold Regions Research and Engineering Laboratory Research Report 297, 111 p.

1973, Water balance in the Arctic and subarctic regionsannotated bibliography and preliminary assessment: Hanover, N.H., U.S. Army Corps of Engineers, Cold Regions Research and Engineering Laboratory Special Report 187, $131 \mathrm{p}$.

Dingman, S.L., Barry, R.G., Weller, Gunter, Benson, C.S., LeDrew, E.F., and Goodwin, C.W., 1980, Climate, snow cover, microclimate, and hydrology, in Brown, Jerry, Miller, P.C., Tieszen, L.L., and Bunnell, F.L., eds., An Arctic ecosystem-the coastal tundra at Barrow, Alaska: Stroudsburg, Pa., Dowden, Hutchinson \& Ross, p. 30-70.

Dingman, S.L., and Koutz, F.R., 1974, Relations among vegetation, permafrost, and potential insulation in central Alaska: Arctic and Alpine Research, v. 6, no. 1, p. 37-42.

Dolan, T.J., Hermann, A.J., Bayley, Suzanne, and Zoltek, John, 1984, Evapotranspiration of a Florida, U.S.A., freshwater wetland: Journal of Hydrology, v. 74, p. 355-371.

Dubinski, B.J., Simpson, R.L., Good, R.E., 1986, The retention of heavy metals in sewage sludge applied to a freshwater tidal wetland: Estuaries, v. 9, no. 2, p. 102-111.

Dudley, W.W., Jr., and Larson, J.D., 1976, Effect of irrigation pumping on desert Pupfish habitats in Ash Meadows, Nye County, Nevada: U.S. Geological Survey Professional Paper $927,52 \mathrm{p}$.

Eckhardt, B.W., and Moore, T.R., 1990, Controls on dissolved organic carbon concentrations in streams, southern Quebec: Canadian Journal of Fisheries and Aquatic Sciences, v. 47, p. 1537-1544.

Elder, J.F., 1985, Nitrogen and phosphorus speciation and flux in a large Florida river wetland system: Water Resources Research, v. 21, no. 5, p. 724-732.

1987, Factors affecting wetland retention of nutrients, metals, and organic materials, in Kusler, J.A., and Brooks, Gail, eds., Wetland hydrology: National Wetland Symposium, 1987, Proceedings, p. 178-184.

Environmental Defense Fund, 1992, How wet is a wetland?: Washington, D.C., World Wildlife Fund, 175 p.

Ewel, K.C., and Odum, H.T., eds., 1984, Cypress swamps: Gainesville, Fla., University of Florida Press, 472 p.

Ewel, K.C., and Smith, J.E., 1992, Evapotranspiration from Florida pondcypress swamps: Water Resources Bulletin, v. 28 , no. 2, p. 299-304.

Ford, Jesse, and Bedgord, B.L., 1987, The hydrology of Alaskan wetlands, U.S.A.- a review: Arctic and Alpine Research, v. 19 , no. 3, p. 209-229.

Foster, D.R., and Jacobson, H.A., 1990, The comparative development of bogs and fens in central Sweden-Evaluating the role of climate change and ecosystem development: Aquilo Service Botany, v. 28, p. 15-26.

Foster, D.R., and Wright, H.E., 1990, Role of ecosystem development and climate change in bog formation in central Sweden: Ecology, v. 7, no. 2, p. 450-463.

Freeze, R.A., and Banner, James, 1970, The mechanism of natural ground-water recharge and discharge: Water Resources Research, v. 6, no. 1, p. 138-155.

Freeze, R.A., and Cherry, J.A., 1979, Groundwater: Englewood Cliffs, N.J., Prentice-Hall, 604 p. 
Gannon, P.T., Sr., Bartholic, J.F., and Bill, R.G., Jr., 1979, Climatic and meteorological effects of wetlands, in Greeson, P.E., Clark, J.R., and Clark, J.E., eds., Wetland functions and values - the state of our understanding: National Symposium on Wetlands, Lake Buena Vista, Fla., 1978, Proceedings: Minneapolis, Minn., American Water Resources Association, p. 576-588.

Gehrels, Jim, and Mulamoottil, George, 1990, Hydrologic processes in a southern Ontario wetland: Hydrobiologia, v. 208, p. 221-234.

Giblin, A.E., 1985, Comparisons of the processing of elements by ecosystems, II, metals: in Godfrey, P.J., Kaynor, E.R., Pelczarski, Sheila, and Benforado, Jay, eds., Ecological considerations in wetlands treatment of municipal wastewaters: New York, Van Nostrand Reinhold, p. 158-179.

Gieck, R.E., Jr., 1986, Hydrology of two subarctic watersheds: in Kane, D.L., Symposium on Cold Regions Hydrology, Fairbanks, Alaska, 1986, Proceedings, p. 283-291.

Gillham, R.W., 1984, The capillary fringe and its effect on watertable response: Journal of Hydrology, v. 67, p. 307-324.

Glaser, P.H., Jannssens, J.A., and Siegel, D.I., 1990, The response of vegetation to chemical and hydrological gradients in the Lost River Peatland, northern Minnesota: Journal of Ecology, v. 78, p. 1021-1048.

Godfrey, P.J., Kaynor, E.R., Pelczarski, Sheila, and Benforado, Jay, eds., 1985, Ecological considerations in wetlands treatment of municipal wastewaters: New York, Van Nostrand Reinhold, $473 \mathrm{p}$.

Golet, F.C., and Lowry, D.J., 1987, Water regimes and tree growth in Rhode Island Atlantic white cedar swamps, in Laderman, A.D., ed., Atlantic white cedar wetlands: Boulder, Colo., Westview Press, p. 91-110.

Good, B.J., and Patrick, W.H., Jr., 1987, Root-water-sediment interface processes, in Reddy, K.R., and Smith, W.H., eds., Aquatic plants for water treatment and resource recovery: Orlando, Florida, Magnolia Publishing Company, p. 359-371.

Good, R.E., Whigham, D.F., and Simpson, R.L., eds., 1978, Freshwater wetlands - ecological processes and management potential: New York, Academic Press, 378 p.

Gore, A.J.P., ed., 1983a, Ecosystems of the world, 4A, Miresswamp, bog, fen and moor: New York, Elsevier Science Publishers, $440 \mathrm{p}$.

$1983 \mathrm{~b}$, Ecosystems of the world, 4B, Mires-swamp, bog, fen and moor: New York, Elsevier Science Publishers, $479 \mathrm{p}$.

Gorham, Eville, Eisenreich, S.J., Ford, Jesse, and Santelmann, M.V., 1985, The chemistry of bog waters, in Stumm, Werner, ed., Chemical processes in lakes: New York, John Wiley, p. $339-362$.

Gosselink, J.G., Lee, L.C., and Muir, T.A., eds. 1990, Ecological processes and cumulative impacts: Chelsea, Mich., Lewis Publishers, Inc., $708 \mathrm{p}$.

Gosselink, J.G., and Turner, R.E., 1978, The role of hydrology in freshwater wetland ecosystems, in Good, R.E., Whigham, D.F., and Simpson, R.L., eds., Freshwater wetlands, ecological processes and management potential: New York, Academic Press, p. 63-78.

Guntenspergen, G.R., and Stearns, Forrest, 1985, Ecological perspectives on wetland systems, in Godfrey, P.J., and Kaynor, E.R., Pelczarski, Sheila, and Benforado, Jay, eds., Ecological considerations in wetlands treatment of municipal wastewaters: New York, Van Nostrand Reinhold, p. 69-97.

Hains, C.F., 1973, Floods in Alabama-magnitude and frequency based on data through September 30, 1971: Montgomery, Ala., Alabama Highway Department, 38 p.
Hammer, D.A., ed., 1989, Constructed wetlands for wastewater treatment-municipal, industrial, and agricultural: Chelsea, Mich., Lewis Publishers, Inc., 831 p.

1992, Creating freshwater wetlands: Chelsea, Mich. Lewis Publishers, Inc., 298 p.

Harvey, J.W., and Odum, W.E., 1990, The influence of tidal marshes on upland groundwater discharge to estuaries: Biogeochemistry, v. 10, p. 217-236.

Hemond, H.F., Army, T.P., Nuttle, W.K., and Chen, D.G., 1987, Element cycling in wetlands-interactions with physical mass transport, in Hites, R.A., and Eisenreich S.J., eds., Sources and fates of aquatic pollutants: American Chemical Society Advances in Chemistry Series 216, p. 519-537.

Hemond, H.F., and Fifield, J.L., 1982, Subsurface flow in salt marsh peat-a model and field study: Limnology and Oceanography, v. 27, no. 1, p. 126-136.

Hemond, H.F., Nuttle, W.K., Burke, R.W., and Stolzenbach, K.D., 1984, Surface infiltration in salt marshes-theory, measurement, and biogeochemical implications: Water Resources Research, v. 20, no. 5, p. 591-600.

Hill, A.R., 1990a, Ground water cation concentrations in the riparian zone of a forested headwater stream: Hydrological Processes, v. 4, p. 121-130.

$1990 \mathrm{~b}$, Ground water flow paths in relation to nitrogen chemistry in the near-stream zone: Hydrobiologia, v. 206, p. 39-52.

Hill, B.M., and Siegel, D.I., 1991, Groundwater flow and the metal content of peat: Journal of Hydrology, v. 123, p. 211-224.

Hofsetter, R.H., 1983, Wetlands in the United States, in Gore, A.J.P., ed., Ecosystems of the world, 4B, Mires-swamp, bog, fen and moor: New York, Elsevier Science Publishers, p. 201-244.

Hopkins, D.M., Karlstrom, T.N., Black, R.F., and others, 1955, Permafrost and ground water in Alaska: U.S. Geological Survey Professional Paper 264-F, p. 113-146.

Hubbard, D.E., and Linder, R.L., 1986, Spring runoff retention in prairie pothole wetlands: Journal of Soil and Water Conservation, v. 41 , no. 2 , p. 122-125.

Hurr, R.T., 1983, Ground-water hydrology of the Mormon Island Crane Meadows Wildlife Area near Grand Island, Hall County, Nebraska: U.S. Geological Survey Professional Paper 1277-H, p. H1-H12.

Hyatt, R.A., and Brook, G.A., 1984, Ground water flow in the Okefenokee Swamp and hydrologic and nutrient budgets for the period August 1981-July 1982, in Cohen, A.D., Casagrande, D.J., Andrejko, M.J., and Best, G.R., eds., The Okefenokee Swamp-its natural history, geology, and geochemistry: Los Alamos, New Mex., Wetland Surveys, p. 229-245.

Idso, S.B., 1981, Relative rates of evaporative water losses from open and vegetation covered water bodies: Water Resources Bulletin, v. 17, no. 1, p. 46-48.

Ingram, H.A.P., 1983, Hydrology, in Gore, A.J.P, ed., Ecosystems of the world, 4A, Mires-swamp, bog, fen and moor: New York, Elsevier Science Publishers, p. 67-158.

Ivanov, K.E., 1981, Water movement in mirelands: New York, Academic Press, 276 p.

Jarrett, R.D., and Costa, J.E., 1984, Hydrology, geomorphology, and dam-break modeling of the July 15, 1982, Lawn Lake Dam and Cascade Lake Dam failures, Larimer County, Colorado: U.S. Geological Survey Open-File Report 84-612, 109 p.

Johnston, C.A., Bubenzer, G.B., Lee, G.B., Madison, F.W., and McHenry, J.R., 1984, Nutrient trapping by sediment deposition in a seasonally flooded lakeside wetland: Journal of Environmental Quality, v. 13, no. 2, p. 283-290. 
Johnston, C.A., Detenbeck, N.E., and Niemi, G.J., 1990, The cumulative effect of wetlands on stream water quality and quantity - a landscape approach: Biogeochemistry, v. 10, p. 105141.

Kadlec, R.H., and Bevis, F.B., 1990, Wetlands and wastewater: Wetlands, v. 10, no. 1, p. 77-91.

Kadlec, R.H., Bevis, F.B., Rycroft, D.W., Williams, D.J.A., and Ingram, H.A.P., 1975, The transmission of water through peat, Review: Journal of Ecology, v. 63, p. 535-568.

Kane, D.L., 1980, Snowmelt infiltration into seasonally frozen soils: Cold Regions Science and Technology, v. 3, p. 153-161.

Kane, D.L., Fox, J.D., Siefert, R.D., and Taylor, G.S., 1978, Snowmelt infiltration and movement in frozen soils: International Conference on Permafrost, 3d, Edmonton, Alberta, Canada, 1978, Proceedings, v. 1, p. 201-206.

Kane, D.L., and Slaughter, C.W., 1973, Recharge of a central Alaska lake by subpermafrost groundwater: International Conference on Permafrost, 2d, Yakutsk, Siberia, 1973, Proceedings: p. 458-468.

Kane, D.L., and Stein, Jean, 1983, Field evidence of groundwater recharge in interior Alaska: International Conference on Permafrost, 4th, Fairbanks, Alaska, 1983, Proceedings, p. 572-577.

Kelly, J.R., and Harwell, M.A., 1985, Comparisons of the processing of elements by ecosystems; v. I, Nutrients, in Godfrey, P.J., Kaynor, E.R., Pelczarski, Sheila, and Benforado, Jay, eds., Ecological considerations of wetlands treatment of municipal wastewaters: New York, Van Nostrand Reinhold, p. 137-157.

Kenoyer, G.J., and Anderson, M.P., 1989, Goundwater's dynamic role in regulating acidity and chemistry in a precipitationdominated lake: Journal of Hydrology, v. 109, p. 287-306.

Koerselman, Willem, and Beltman, Boudewijn, 1988, Evapotranspiration from fens in relation to Penman's potential free water evaporation (Eo) and pan evaporation: Aquatic Botany, v. 31, p. $307-320$.

Kratz, T.K., and DeWitt, C.B., 1988, Internal factors controlling peatland-lake ecosystem development: Ecology, v. 67, no. 1, p. 100-107.

LaBaugh, J.W., 1986, Limnological characteristics of selected lakes in the Nebraska sandhills, U.S.A., and their relation to chemical characteristics of adjacent ground water: Journal of Hydrology, v. 86, p. 279-298.

LaBaugh, J.W., Winter, T.C., Adomaitis, V.A., and Swanson, G.A., 1987, Hydrology and chemistry of selected prairie wetlands in the Cottonwood Lake area, Stutsman County, North Dakota, 1979-82: U.S. Geological Survey Professional Paper $1431,26 \mathrm{p}$.

Lafleur, P.M., and Roulet, N.T., 1992, A comparison of evaporation rates from two fens of the Hudson Bay lowland: Aquatic Botany, v. 44, p. 59-69.

Leibowitz, S.G., Abbruzzese, Brooks, Adamus, P.R., Hughes, L.E., and Irish, J.T., 1992, Synoptic approach to cumulative impact assessment: a proposed methodology: U.S. Environmental Protection Agency, EPA/600/R-92/167, 138 p.

Leitman, H.M., Sohm, J.E., and Franklin, M.A., 1983, Wetland hydrology and tree distribution of the Apalachicola River flood plain: U.S. Geological Survey Water-Supply Paper 2196-A, 52 p.

Lichtler, W.F., and Walker, P.N., 1974, Hydrology of the Dismal Swamp, Virginia-North Carolina: U.S. Geological Survey Open-File Report 74-0039, 67 p.

Linacre, E.T., Hicks, B.B., Sainty, G.R., and Grauze, G., 1970, The evaporation from a swamp: Agricultural Meteorology, v. 7, p. 375-386.
Lissey, A., 1971, Depression-focused transient groundwater flow patterns in Manitoba: Geological Association of Canada Special Paper 9, p. 333-341.

Ludden, A.P., Frink, D.L., and Johnson, D.H., 1983, Water storage capacity of natural wetland depression in the Devils Lake Basin of North Dakota: Journal of Soil and Water Conservation v. 38 , no. 1 , p. $45-48$.

Luthin, J.N., and Guymon, G.L., 1974, Soil moisture-vegetationtemperature relationships in central Alaska: Journal of Hydrology, v. 23, p. 233-246.

Marin, L.E., Kratz, T.K., and Bowser, C.J., 1990, Spatial and temporal patterns in the hydro-geochemistry of a poor fen in northern Wisconsin: Biogeochemistry, v. 2, p. 63-76.

McNamara, J.P., Siegel, D.I., Glaser, P.H., and Beck, R.M., 1992, Hydrogeologic controls on peatland development in the Malloyville wetland, New York (U.S.A.): Journal of Hydrology, v. 140, p. 279-296.

Meyboom, Peter, 1964, Three observations on streamflow depletion by phreatophytes: Journal of Hydrology, v. 2, p. 248-261.

1967, Mass-transfer studies to determine the groundwater regime of permanent lakes in hummocky moraine of western Canada: Journal of Hydrology, v. 5, p. 117-142.

Meyboom, Peter, Everdingen, R.O. van, and Freeze, R.A., 1966, Patterns of groundwater flow in seven discharge areas in Saskatchewan and Manitoba: Geological Survey of Canada Bulletin 147, $54 \mathrm{p}$.

Miller, E.G., 1965, Effect of Great Swamp, New Jersey, on streamflow during base-flow periods, in Geological Survey Research 1965, U.S. Geological Survey Professional Paper 525-B, p. B177-B179.

Mitsch, W.J., Dooge, C.L., and Wiemhoff, J.R., 1979, Ecosystem dynamics and a phosphorus budget of an alluvial cypress swamp in southern Illinois: Ecology, v. 60 , no. 6, p. 11161124.

Mitsch, W.J., and Gosselink, J.G., 1993, Wetlands (2d ed.): New York, Van Nostrand Reinhold, 722 p.

Moore, I.D., and Larsen, C.L., 1979, Effects of drainage projects on surface runoff from small depressional watersheds in the North Central Region: Water Resources Bulletin 99, 151 p.

Moore, T.R., 1989, Plant production, decomposition, and carbon efflux in a subarctic patterned fen: Arctic and Alpine Research, v. 21, no. 2, p. 156-162.

Morton, R.B., Goering, J.D., and Dollhopf, D.J., 1989, Hydrologic characteristics of a wetland using a bromide tracer, in Woessner, W.W., and Potts, D.F., eds., Symposium on Headwaters Hydrology, Helena, Mont., 1989, Proceedings, p. 553-562.

Munro, S.D., 1986, On forested wetlands as evaporators: Revue Canadian des Resources en Eau, v. 11, no. 1, p. 89-99.

Nichols, D.S., and Brown, J.M., 1980, Evaporation from a sphagnum moss surface: Journal of Hydrology, v. 438, p. 289-302.

Novitzki, R.P., 1978, Hydrology of the Nevin Wetland near Madison, Wisconsin: U.S. Geological Survey Water-Resources Investigations 78-48, $25 \mathrm{p}$.

1979, Hydrologic characteristics of Wisconsin's wetlands and their influence on floods, stream flow, and sediment, in Greeson, P.E., Clark, J.R., and Clark, J.E., eds., Wetland functions and values - the state of our understanding: National Symposium on Wetlands, Lake Buena Vista, Fla., 1978, Proceedings: Minneapolis, Minn., American Water Resources Association, p. 377-388.

1982, Hydrology of Wisconsin wetlands: Wisconsin Geological and Natural History Survey Information Circular 40, $22 \mathrm{p}$. 
1989, Wetland hydrology, in Majumdar, S.K., Brooks, R.P., Brenner, F.J., and Tiner, R.W., Jr., eds., Chapter five, Wetlands ecology and conservation-emphasis in Pennsylvania: Philadelphia, Pa., Pennsylvania Academy of Science, $p$. 47-64.

O'Brien, A.L., 1977, Hydrology of two small wetland basins in eastern Massachusetts: Water Resources Bulletin, v. 13, p. 325-340.

1980 , The role of ground water in stream discharges from two small wetland controlled basins in eastern Massachusetts: Ground Water, v. 18, no. 4, p. 359-364.

1988 , Evaluating the cumulative effects of alteration on New England wetlands: Environmental Management, v. 12, no. 5, p. 627-636.

Ogawa, Hisashi, and Male, J.W., 1986, Simulating of flood mitigation role of wetlands: Journal of Water Resources Planning and Management, v. 112, no. 1, p. 114-127.

Osterkamp, W.R., and Wood, W.W., 1987, Playa-lake basins on the southern High Plains of Texas and New Mexico; Part 1, Hydrologic, geomorphic and geologic evidence for their development: Geological Society of America Bulletin, v. 99, p. 215-223.

Owen, D.E., Otton, J.K., Hills, F.A., and Schumann, R.R., 1992, Uranium and other elements in Colorado Rocky Mountain wetlands-a reconnaissance study: U.S Geological Survey Bulletin 1992, 33 p.

Phillips, J.D., 1989, Fluvial sediment storage in wetlands: Water Resources Bulletin, v. 25, no. 4, p. 867-873.

Phillips, P.J., and Shedlock, R.J., 1993, Hydrology and chemistry of groundwater and seasonal ponds in the Atlantic Coastal Plain in Delaware, U.S.A.: Journal of Hydrology, v. 141, p. 157-178.

Preston, E.M., and Bedford, B.L., 1988, Evaluating cumulative effects on wetland functions-a conceptual overview and generic framework: Environmental Management, v. 12, no. 5, p. 565-583.

Price, J.S., and Woo, Ming-Ko, 1988, Studies of a subarctic coastal marsh, I-hydrology: Journal of Hydrology, v. 103, p. 275-292.

Priestley, C.H.B., and Taylor, R.J., 1972, On the assessment of surface heat flux and evaporation using large-scale parameters: National Oceanic and Atmospheric Administration, Monthly Weather Review, v. 100, no. 2, p. 92.

Reddy, K.R., and Smith, W.H., eds., 1987, Aquatic plants for water treatment and resource recovery: Orlando, Fla., Magnolia Publishing Co., 1032 p.

Richardson, C.J., Tilton, D.L., Kadlec, J.A., Chamie, J.P.M., and Wentz, W.A., 1978, Nutrient dynamics of northern wetland ecosystems, in Good, R.E., Whigham, D.F., and Simpson, R.L., eds., Freshwater wetlands: New York, Academic Press, p. 217-241.

Roulet, N.T., 1990, Hydrology of a headwater basin wetlandgroundwater discharge and wetland maintenance: Hydrological Processes, v. 4, p. 387-400.

Roulet, N.T., and Woo, Ming-Ko, 1986, Hydrology of a wetland in the continuous permafrost region: Journal of Hydrology, $v$. 89 , p. 73-91.

Rouse, W.R., Mills, P.F., and Stewart, R.B, 1977, Evaporation in high latitudes: Water Resources Research, v. 13, p. 909-914.

Ruddy, B.C., and Williams, R.S., Jr., 1991, Hydrologic relations between streamflow and subalpine wetlands in Grand County, Colorado: U.S. Geological Survey Water-Resources Investigations Report 90-4129, 53 p.

Rycroft, D.W., Williams, D.J.A., and Ingram, H.A.P., 1975a, The transmission of water through peat, I-review: Journal of
Ecology, v. 63, p. 535-556.

$1975 \mathrm{~b}$, The transmission of water through peat, II-field experiments: Journal of Ecology, v. 63, no. 2, p. 557-568.

Rykiel, E.J., Jr., 1984, General hydrology and mineral budgets for Okefenokee Swamp-ecological significance, in Cohen, A.D., Casagrande, D.J., Andrejko, M.J., and Best, G.R., eds., The Okefenokee Swamp-its natural history, geology, and geochemistry: Los Alamos, New Mex.: Wetland Surveys, p. 212-228.

Sather, J.H., and Smith, R.D., 1984, An overview of major wetland functions and values: U.S. Fish and Wildlife Service, Office of Biological Services Report OBS-84, 68 p.

Schwintzer, C.R., and Tomberlin, T.J., 1982, Chemical and physical characteristics of shallow ground waters in northern Michigan bogs, swamps, and fens: American Journal of Botany, v. 69, no. 8, p. 1231-1239.

Sharitz, R.R., and Gibbons, J.W., 1982, The ecology of southeastern shrub bogs (pocosins) and Carolina bays-a community profile: U.S. Fish and Wildlife Service, Office of Biological Services Report FWS/OBS-82/04, 93 p.

Shedlock, R.J., Wilcox, D.A., Thompson, T.A., and Cohen, D.A., 1993, Interactions between ground water and wetlands, southern shore of Lake Michigan, U.S.A.: Journal of Hydrology, v. 141 , p. $127-155$.

Siegel, D.I., 1983, Ground water and the evolution of patterned mires, glacial Lake Agassiz peatlands, northern Minnesota: Journal of Ecology, v. 71, p. 913-921.

1988a, Evaluating cumulative effects of disturbance on the hydrologic function of bogs, fens, and mires: Environmental Management, v. 12, no. 5, p. 621-626.

$1988 \mathrm{~b}$, The recharge-discharge function of wetlands near Juneau, Alaska; Part I, Hydrogeological investigation: Ground Water, v. 26, no. 4, p. 427-434.

$1988 \mathrm{c}$, The recharge-discharge function of wetlands near Juneau, Alaska, Part II, Geochemical investigation: Ground Water, v. 26 , no. 5 , p. $580-586$.

1992, Groundwater hydrology, in Wright, H.E., Coffin, B.A., and Aaseng, N.E., eds., The patterned peatlands of Minnesota: Minneapolis, Minn., University of Minnesota Press, p. 163-172.

Siegel, D.I., and Glaser, P.H., 1987, Groundwater flow in a bogfen complex, Lost River Peatland, northern Minnesota: Journal of Ecology, v. 75, p. 743-754.

Simpson, R.L., Good, R.E., Walker, Raymond, and Frasco, B.R., 1983, The role of Delaware River freshwater tidal wetlands in the retention of nutrients and heavy metals: Journal of Environmental Quality, v. 12, no. 1, p. 41-48.

Slaughter, C.W., Hilgert, J.W., and Culp, E.H., 1983, Summer streamflow and sediment yield from discontinuous-permafrost headwaters catchments: International Conference on Permafrost, 4th, Fairbanks, Alaska, 1983, Proceedings: Washington, D.C., National Academy Press, p. 1172-1177.

Slaughter, C.W., and Kane, D.L., 1979, Hydrologic role of shallow organic soils in cold climates-Canadian Hydrology Symposium 79-Cold Climate Hydrology, Ottawa, Canada, 1979: Ottawa, Canada, National Research Council of Canada, p. 380-389.

Stagnitti, F., Parlang, J.Y., and Rose, C.W., 1989, Hydrology of a small wet catchment: Hydrological Processes, v. 3, p. 137-150.

Steinwand, A.L., and Richardson, J.L., 1989, Division S-5-soil genesis, morphology, and classification: American Journal of Soil Science, v. 53, p. 836-842.

Stewart, R.E., and Kantrud, H.A., 1971, Classification of natural ponds and lakes in the glaciated prairie region: U.S. Fish and Wildlife Service Resource Publication 92, 57 p. 
Stone, J.H., Bahr, L.M., Jr., and Day, J.W., 1978, Effects of canals on freshwater marshes in coastal Louisiana and implications for management, in Good, R.E., Whigham, D.F., and Simpson, R.L., eds., Freshwater wetlands: New York, Academic Press, p. 299-320.

Striegl, R.G., 1987, Suspended sediment and metals removal from urban runoff by a small lake: Water Resources Bulletin, v. 23 , no. 6, p. 985-996.

Swanson, D.K., and Grigal, D.F., 1991, Biomass, structure, and trophic environment of peatland vegetation in Minnesota: Wetlands, v. 11, no. 2, p. 279-302.

Swanson, G.A., Winter, T.C., Adomaitis, V.A., and LaBaugh, J.W., 1988, Chemical characteristics of prairie lakes in southcentral North Dakota - their potential for influencing use by fish and wildlife: U.S. Fish and Wildlife Service Technical Report 18, 46 p.

Taylor, C.H., and Pierson, D.C., 1985, The effect of a small wetland on runoff response during spring snowmelt: Atmosphere-Ocean, v. 23, no. 2, p. 138-154.

Taylor, J.R., Cardamone, M.A., and Mitsch, W.J., 1990, Bottomland hardwood forests - their functions and values, in Gosselink, J.G., Lee, L.C., and Muir, T.A., eds., Ecological processes and cumulative impacts: Chelsea, Mich., Lewis Publishers, Inc., p. 13-86.

Thompson, C.A., Bettis, E.A., III, and Baker, R.G., 1992, Geology of Iowa fens: Journal of the Iowa Academy of Sciences, v. 99, p. $53-59$.

Tice, R.H., 1968, Magnitude and frequency of floods in the United States: U.S. Geological Survey Water-Supply Paper $1672,13 \mathrm{p}$.

Tilton, D.L., and Kadlec, R.H., 1979, The utilization of a freshwater wetland for nutrient removal from secondarily treated waste water effluent: Journal of Environmental Quality, v. 8, no. 3, p. 328-334.

Tiner, R.W., 1984, Wetlands of the United States-current status and recent trends: Washington, D.C., U.S. Fish and Wildlife Service Report, 59 p.

Tiner, R.W., Jr., 1985, Wetlands of New Jersey, Newton Corner, Mass., U.S. Fish and Wildlife Service, National Wetlands Inventory, $117 \mathrm{p}$.

Valiela, Ivan, and Costa, J.E., 1988, Eutrophication of Buttermilk Bay, a Cape Cod coastal embayment - concentrations of nutrients and watershed nutrient budgets: Environmental Management, v. 12 , no. 4 , p. 539-553.

Valiela, Ivan, Costa, J.E., Foreman, Kenneth, Teal, J.M., Howes, Brian, and Aubrey, David, 1990, Transport of groundwaterborne nutrients from watersheds and their effects on coastal waters: Biogeochemistry, v. 10, p. 177-197.

Valiela, Ivan, Teal, J.M., Volkmann, Susanne, Shafer, Deborah, and Carpenter, E.J., 1978, Nutrient and particulate fluxes in a salt marsh ecosystem - tidal exchanges and inputs by precipitation and groundwater: Limnology and Oceanography, v. 23, no. 4 , p. $708-812$.

Vecchioli, John, Gill, H.E., and Land, S.M., 1962, Hydrologic role of the Great Swamp and other marshland in upper Passaic River Basin: Journal of the American Water Works Association, v. 54, p. 695-701.

Verry, E.S., and Boelter, D.H., 1979, Peatland hydrology, in Greeson, P.E., Clark, J.R., and Clark, J.E., eds., Wetland functions and values-the state of our understanding: National Symposium on Wetlands, Lake Buena Vista, Fla., 1978, Proceedings: Minneapolis, Minn., American Water Resources Association, p. 389-402.

Vitt, D.H., and Slack, N.G., 1975, An analysis of the vegetation of sphagnum-dominated kettle-hole bogs in relation to envi- ronmental gradients: Canadian Journal of Botany, v. 53, no. 4, p. 332-359.

Walbridge, M.R., and Richardson, C.J., 1991, Water quality of pocosins and associated wetlands of the Carolina Coastal Plain: Wetlands, v. 2, p. 417-439.

Wharton, C.H., 1977, The natural environments of Georgia: Atlanta, Ga., Georgia Department of Natural Resources, Office of Planning and Research, $227 \mathrm{p}$.

Whiteley, H.R., and Irwin, R.W., 1986, The hydrological response of wetlands in southern Ontario: Canadian Water Resources Journal, v. 11, p. 100-110.

Wieder, R.K., 1989, A survey of constructed wetlands for acid coal mine drainage treatment in the eastern United States: Wetlands, v. 9, no. 2, p. 299-315.

Wilcox, D.A., Shedlock, R.J., and Hendrickson, W.H., 1986, Hydrology, water chemistry and ecological relations in the raised mound of Cowles Bog: Journal of Ecology, v. 74, p. 1103-1117.

Williams, J.R., and Everdingen, R.O. van, 1973, Groundwater investigations in permafrost regions of North America-a review: International Conference on Permafrost, 2d, session Yakutsk, Siberia, 1973, Proceedings, p. 435-446.

Williams, J.R., and Waller, R.M., 1966, Ground water occurrence in permafrost regions of Alaska: Washington, D.C., National Research Council, p. 159-164.

Winkler, M.G., 1988, Effect of climate on development of two sphagnum bogs in south-central Wisconsin: Ecology, v. 69, p. 1032-1043.

Winograd, I.J., and Thordarson, William, 1975, Hydrogeologic and hydrochemical framework, south-central Great Basin, NevadaCalifornia, with special reference to the Nevada Test Site: U.S. Geological Survey Professional Paper 712-C, 126 p.

Winter, T.C., 1976, Numerical simulation analysis of the interaction of lakes and ground water: U.S. Geological Survey Professional Paper 1001, $45 \mathrm{p}$.

1981, Uncertainties in estimating the water balance of lakes: Water Resources Bulletin, v. 17, no. 1, p.82-115.

1986, Effect of ground-water recharge on configuration of the water table beneath sand dunes and on seepage in lakes in the sandhills of Nebraska, U.S.A.: Journal of Hydrology, v. 86, p. 221-237.

1992, A physiographic and climatic framework for hydrologic studies of wetlands: Symposium on Aquatic Ecosystems in Semi-Arid Regions, Saskatoon, Saskatchewan, 1990: Environment Canada, National Hydrology Research Institute Symposium Series 7, 44 p.

Winter, T.C., and Woo, Ming-Ko, 1990, Hydrology of lakes and wetlands-surface water hydrology, in, Wolman, M.G., and Riggs, H.C., eds., Surface Water Hydrology, v. O-1 of Geology of North America: Boulder, Colo., Geological Society of America, p. 159-187.

Woo, Ming-Ko, 1980, Hydrology of a small lake in the Canadian high Arctic: Arctic and Alpine Research, v. 12, no. 2, p. 227 235.

Woo, Ming-Ko, and Heron, Richard, 1987, Effects of forests on wetland runoff during spring: Symposium on Forest Hydrology and Watershed Management, International Association of Hydrological Sciences-Association Internationale des Sciences Hydrologique Publication, p. 297-307.

Woo, Ming-Ko, Heron, Richard, and Steer, Peter, 1981, Catchment hydrology of a high Arctic lake: Cold Regions Science and Technology, v. 5, p. 29-41.

Woo, Ming-Ko, and Marsh, Philip, 1990, Response of soil moisture change to hydrological processes in a continuous permafrost environment: Nordic Hydrology, v. 21, p. 235-252. 
Woo, Ming-Ko, and Valverde, Juan, 1981, Summer streamflow and water level in a midlatitude forested swamp: Forest Science, v. 27 , no. 1 , p. 177-189.

Wood, M.E., Kelley, J.T., and Belknap, D.F., 1989, Patterns of sediment accumulation in the tidal marshes of Maine: Estuaries, v. 12 , no. 4 , p. $237-246$.

Wood, W.W., and Jones, B.F., 1990, Origin of solutes in saline lakes and springs on the southern High Plains of Texas and New Mexico: The University at Austin [Texas], Bureau of Economic Geology, p. 193-208.

Wood, W.W., and Osterkamp, W.R., 1984, Recharge to the Ogallala Aquifer from playa lake basins on the Llano Estacado, in Wetstone, G.A., ed., Ogallala Aquifer Symposium, 2d, Lubbock, Tex., 1984, Proceedings, p. 337-349.

1987, Playa-lake basins on the southern High Plains of Texas and New Mexico; Part II, A hydrologic model and mass-balance arguments for their development: Geological Society of America Bulletin, v. 99, p. 224-230.

Wood, W.W., and Sanford, W.E., 1994, Recharge to the Ogallala: 60 years after C.V. Theis' analysis, in Urban, L.V., and Wyatt, A.W., eds., Playa Basin Symposium, Lubbock, Tex., Texas Tech University, 1994, Proceedings, p. 23-33.

Wright, H.E., Jr., Coffin, B.A., and Aaseng, N.E., eds., 1992, The patterned peatlands of Minnesota: Minneapolis, Minn., University of Minnesota Press, $327 \mathrm{p}$.

Zack, Allen, and Roman-Mas, Angel, 1988, Hydrology of the Caribbean island wetlands: Acta Cientifica, v. 2, p. 65-73.

Zedler, J.B., 1982, The ecology of southern California coastal salt marshes-a community profile: U.S. Fish and Wildlife Service, Office of Biological Services Report FWS/OBS-81/54, $110 \mathrm{p}$.

Zedler, J.B., Huffman, Terry, and Josselyn, M.N., eds., 1985, Pacific regional wetland functions: Workshop, Mill Valley, Calif., 1985, Proceedings : Amherst, Mass., University of Massachusetts, The Environmental Institute, Publication 90-3, $162 \mathrm{p}$.

\section{Wetlands as Bird Habitat}

American Ornithologists' Union, 1983, Check-list of North American birds (6th ed.): Lawrence, Kans., Allen Press, Inc., $877 \mathrm{p}$.

Anderson, J.T., 1994, Wetland use and selection by waterfowl wintering in coastal Texas: College Station, Tex., Texas A\&M University, M.S. thesis, 318 p.: Masters Abstracts International, v. 32, no. 5, p. 1320.

Baldassare, G.A., and Bolen, E.G., 1994, Waterfowl ecology and management: New York, John Wiley, 609 p.

Ball, J.P., and Nudds, T.D., 1989, Mallard habitat selection-an experiment and implications formanagement, in Sharitz, R.R., and Gibbons, J.W., eds., Freshwater wetlands and wildlife: Department of Energy Symposium Series 61, Charleston, S.C., 1986, Proceedings: U.S. Department of Energy Conference CONF-8603101, p. 659-671.

Bauer, D.W., 1993, Avian use of wetlands in southern Texas during non-breeding seasons: College Station, Tex., Texas A\&M University, M.S. thesis, 171 p.: Masters Abstracts International, 1994, v. 32, no. 3, p. 883.

Bellrose, F.C., 1977, Species distribution, habitats, and characteristics of breeding dabbling ducks in North America, in Bookhout, T.A., Waterfowl and wetlands-an integrated review, Midwest Fish and Wildlife Conference, 39th, Madison, Wis., 1977, Proceedings of symposium: La Crosse, Wis., La Crosse Printing Co., Inc., $152 \mathrm{p}$.

Bellrose, F.C., and Trudeau, N.M., 1988, Wetlands and their relationship to migrating and winter populations of waterfowl, in
Hook, D.D., McKee, W.H., Jr., Smith, H.K., and others, eds., The ecology and management of wetlands, v. I, The ecology of wetlands: Portland, Oreg., Timber Press, p. 183-194.

Bookhout, T.A., 1979, Waterfowl and wetlands-an integrated review, in Bookhout, T.A., ed., Midwest Fish and Wildlife Conference, 39th, Madison, Wis., 1977, Proceedings of symposium: La Crosse, Wis., La Crosse Printing Co., $152 \mathrm{p}$.

Boyd, Hugh, 1981, Prairie dabbling ducks, 1941-1990: Canadian Wildlife Service Program Notes 119, 9 p.

Brown, Mike, and Dismore, J.J., 1986, Implications of marsh size and isolation for marsh bird management: Journal of Wildlife Management, v. 50, no. 3, p. 392-397.

Carter, Virginia, and Novitzki, R.P., 1988, Some comments of the relation between ground water and wetlands, in Hook, D.D., McKee, W.H., Jr., Smith, H.K., and others, eds., The ecology and management of wetlands, v. I, The ecology of wetlands: Portland, Oreg., Timber Press, 592 p.

Crome, F.H.J., 1988, To drain or not to drain? Intermittent swamp drainage and waterbird breeding: Emu, v. 88 , no. 4 , p. $243-$ 248.

Dahl, T.E., Johnson, C.E., and Frayer, W.E., 1991, Wetlandsstatus and trends in the conterminous United States, mid1970's to mid-1980's: Washington, D.C., U.S. Fish and Wildlife Service, $22 \mathrm{p}$.

Davidson, N.C., and Evans, P.R., 1987, Habitat restoration and creation-its role and potential in the conservation of waders: Wader Study Group Bulletin 49, Supplement, p. 139-145.

Day, A.M., 1959, North American waterfowl: Harrisburg, Pa., Stackpole Co., 363 p.

Dick, T.M., 1993, Restored wetlands as management tools for wetland-dependent birds: Pennsylvania Birds, v. 7, no. 1, p. 4-6.

Eldridge, Jan, 1992, Management of habitat for breeding and migrating shorebirds in the midwest: U.S. Fish and Wildlife Service Fish and Wildlife Leaflet 13.2.14, 5 p.

Ehrlich, P.R., Dobkin, D.S., and Wheye, Darryl, 1992, Birds in jeopardy: Stanford, Calif., Stanford University Press, 260 p.

Ensiminger, A.B., 1989, Use of the coastal wetlands and barrier islands by migratory birds: New Orleans, La., Louisiana Land and Exploration Co., 6 p.

Erwin, R.M., Coulter, Malcolm, and Cogswell, Howard, 1986, The use of natural vs. man-modified wetlands by shorebirds and waterbirds: Colonial Waterbirds, v. 9, no. 2, p. 137-138.

Evens, Jules, and Stallcup, R.W., 1991, Coastal riparian marsh: Journal of Field Ornithology, v. 62, Supplement, p. 75-76.

Field, D.W., 1991, Coastal wetlands of the United States-an accounting of a valuable national resource: Washington, D.C., U.S. Fish and Wildlife Service and National Oceanic and Atmospheric Administration, $59 \mathrm{p}$.

Fleming, D.M., Wilfried, F.W., and DeAngelis, D.L., 1994, Importance of landscape heterogeneity to wood storks in Florida Everglades: Environmental Management, v. 18, no. 5, p. 743-757.

Fog, Jorgen, and Scott, D.A., 1982, Managing wetlands and their birds-a manual of wetland and waterfowl management, in Technical Meeting On Western Palearctic Migratory Bird Management, 3d, Biologische Station Rieselfelder Munster, Federal Republic of Germany: Proceedings: Slimbridge, England, International Waterfowl Research Bureau, 368 p.

Frayer, W.E., Monahan, T.J., Bowden, D.C., and Graybill, F.A., 1983, Status and trends of wetlands and deepwater habitats in the conterminous United States, 1950's to 1970's: Ft. Collins, Colo., Colorado State University, 32 p.

Fredrickson, L.H., and Heitmeyer, M.E., 1988, Waterfowl use of forested wetlands of the southern United States-an overview, in Weller, M.W., ed., Waterfowl in winter-selected pa- 
pers from symposium and workshop held in Galveston, Tex., 1985: Minneapolis, Minn., University of Minnesota Press, p. 307-323

Fredrickson, L.H., and Reid, F.A., 1988, Waterfowl use of wetland complexes: U.S. Fish and Wildlife Service Fish and Wildlife Leaflet 13.2.1, 6 p.

Fredrickson, L.H., and Taylor, T.S., 1982, Management of seasonally flooded impoundments for wildlife: Washington, D.C., U.S. Fish and Wildlife Service, 29 p.

Gabrielson, I.N., 1947, Wildlife conservation: New York, Macmillan, $250 \mathrm{p}$.

Giron, B.A., 1981, Wildlife use of man-made wetlands in the prairie pothole region-a selected annotated bibliography: Brookings, S.Dak., South Dakota State University, South Dakota Cooperative Wildlife Research Unit, 23 p.

Golet, F.C., 1973, Classification and evaluation of freshwater wetlands as wildlife habitat in the glaciated northeast: Ann Arbor, Mich., University Microfilms, 179 p.

Goss-Custard, J.D., and Yates, M.G., 1992, Towards predicting the effect of salt-marsh reclamation on feeding bird numbers on the wash: Journal of Applied Ecology, v. 29, no. 2, p. 330-340.

Gray, B.T., Gordon, D.H., and Kaminski, R.M., 1987, Functional attributes of coastal wetlands for waterfowl-Perspectives for research and management, in Whitman, W.R., and Meredith, W.H., eds., Symposium on Waterfowl and Wetlands Management in the coastal zone of the Atlantic flyway, Proceedings: Dover, Del., Delaware Department of Natural Resources, Delaware Coastal Management Program, p. 205-222.

Hammer, D.A., 1992, Creating freshwater wetlands: Chelsea, Mich., Lewis Pubishers, Inc., 298 p.

Haukos, D.A., and Smith, L.M., 1993, Moist-soil management of playa lakes for migrating and wintering ducks: Wildlife Society Bulletin, v. 21 , no. 3 , p. 288-298.

Helmers, D.L., 1991, Habitat use by migrant shorebirds and invertebrate availability in a managed wetland complex: Columbia, Mo., University of Missouri, M.S. thesis, 135 p.

Hemesath, L.M., and Dinsmore, J.J., 1993, Factors affecting bird colonization of restored wetlands: Prairie Naturalist, v. 25 , no. 1, p. 1-11.

Hockey, P.A., Navarro, R.A., Kalejta, Bozena, and Velasquez, C.R., 1992, The riddle of the sands-why are shorebird densities so high in southern estuaries?: American Naturalist, v. 140, no.6, p. 961-979.

Hohmann, Kathryn, 1989, Innovation and teamwork in the North American Waterfowl management plan: U.S. Fish and Wildlife Service Fish and Wildlife Leaflet 13.2.2, 5 p.

Hussain, S.A., 1988, Coastal wetlands-major ecological entities for wading and shore birds, in Hook, D.D., McKee, W.H., Jr., Smith, H.K., and others, eds., The ecology and management of wetlands; v. I, The ecology of wetlands: Portland, Oreg., Timber Press, p. 203-212.

Johnson, D.H., and Sargeant, A.B., 1977, Impact of red fox predation on the sex ratio of prairie mallards: U.S. Fish and Wildlife Service Research Report 6, 56 p.

Kantrud, H.A., 1986, Effects of vegetation manipulation on breeding waterfowl in prairie wetlands-a literature review: U.S. Fish and Wildlife Service Fish and Wildlife Technical Report 3, 15 p.

1990 , Effects of vegetation manipulation on breeding waterfowl in prairie wetlands-a literature review: U.S. Forest Service General Technical Report 194, p. 103-110.

Kelly, J.P., 1991, Coastal freshwater marsh: Journal of Field Ornithology, v. 62, Supplement, p. 74-75.

Krapu, G.L., and Duebbert, H.F., 1989, Prairie wetlands-char- acteristics, importance to waterfowl, and status, in Sharitz, R.R., and Gibbons, J.W., eds., Freshwater wetlands and wildlife: Department of Energy Symposium Series 61, Charleston, S.C., 1986, Proceedings: U.S. Department of Energy Conference CONF-8603101, p. 811-828.

Kroodsma, D.E., 1979, Habitat values for nongame wetland birds, in Greeson, P.E., Clark, J.R., and Clark, J.E., eds., Wetland functions and values - the state of our understanding: National Symposium on Wetlands, Lake Buena Vista, Fla., 1978, Proceedings: Minneapolis, Minn., American Water Resources Association, p. 320-343.

Larson, J.S., and Newton, R.B., 1981, The value of wetlands to man and wildlife: Amherst, Mass., U.S. Department of Agriculture, Cooperative Extension Service, University of Massachusetts, 20 p.

Leitch, W.G., and Kaminski, R.M., 1985, Long-term wetland-waterfowl trends in Saskatchewan grasslands: Journal of Wildlife Management, v. 49, p. 212-222.

Magee, P.A., 1993, Waterfowl management handbook: Washington, D.C., U.S. Fish and Wildlife Service, 7 p.

McDonald, C.B., Ash, A.N., Kane, E.S., 1983, Pocosins-a changing wetland resource: Washington, D.C., U.S. Fish and Wildlife Service, $22 \mathrm{p}$.

Merendino, M.T., Dennis, D.G., and Ankney, C.D., 1992, Mallard harvest data-an index of wetland quality for breeding waterfowl: Wildlife Society Bulletin, v. 20, p. 171-175.

Merritt, Antony, 1994, Wetlands, industry, and wildlife-a manual of principles and practices: Slimbridge, England, Wildfowl and Wetlands Trust, $182 \mathrm{p}$.

Mitsch, W.J., and Gosselink, J.G., 1993, Wetlands (2d ed.): New York, Van Nostrand Reinhold, 722 p.

Moyle, J.B., 1964, Ducks and land use in Minnesota: Minnesota Department of Conservation and Technology Bulletin 8, $140 \mathrm{p}$.

Nelson, R.W., Logan, W.J., and Weller, E.C., 1984, Playa wetlands and wildlife on the southern Great Plains-a characterization of habitat: Washington, D.C., Western Energy and Land Use Team, U.S. Environmental Protection Agency, 163 p.

Niering, W.A., 1988, Endangered, threatened and rare wetland plants and animals of the continental United States, in Hook, D.D., McKee, W.H., Jr., Smith, H.K., and others, eds., The ecology and management of wetlands; v. I, The ecology of wetlands: Portland, Oreg., Timber Press, 592 p.

Novara, A.N., 1987, Waterfowl status report: Washington, D.C., U.S. Fish and Wildlife Service, $99 \mathrm{p}$.

Parker, G.R., Petrie, M.J., and Sears, D.T., 1992, Waterfowl distribution relative to wetland acidity: Journal of Wildlife Management, v. 56 , no. 2 , p. 268-274.

Percival, H.F., Montague, C.L., and Zale, A.V., 1987, A summary of positive and negative aspects of coastal wetland impoundments as habitat for waterfowl, in Whitman, W.R., and Meredith, W.H., eds., Symposium on Waterfowl and Wetlands Management, Proceedings: Dover, Del., Delaware Division of Fish and Wildlife Coastal Management Program, p. 224-232.

Petersen, L.R., 1982, Evaluation of waterfowl production areas in Wisconsin: Madison, Wis., Wisconsin Department of Natural Resources, $32 \mathrm{p}$.

Phillips, J.C., and Lincoln, F.C., 1930, American waterfowltheir present situation and the outlook for their future: Boston, Mass., Houghton Mifflin, 312 p.

Poiani, K.A., and Johnson, W.C., 1991, Global warming and prairie wetlands-potential consequences for waterfowl habitat: BioScience, v. 41, no. 9, p. 611-618.

Porter, R.M., and van Kooten, G.C., 1993, Wetlands preservation on the Canadian prairies-the problem of the public duck: 
Canadian Journal of Agricultural Economics, v. 41,p. 401410.

Pulliam, H.R., and Danielson, B.J., 1989, Sources, sinks and habitat selection-a landscape perspective on population dynamics: American Naturalist, v. 137, p. 850-866.

Sharitz, R.R., and Gibbons, J.W., eds., 1989, Freshwater wetlands and wildlife: Department of Energy Symposium Series 61, Charleston, S.C., 1986, Proceedings: U.S. Department of Energy Conference CONF-8603101, 1265 p.

Shaw, S.P., and Fredine, C.G., 1956, Wetlands of the United States-their extent and their value to waterfowl and other wildlife: U.S. Fish and Wildlife Service Circular 39, 67 p.

Shelton, P.A., 1992, Productivity and waterfowl utilization of surface mine wetlands and impoundments: Carbondale, Ill., Southern Illinois University, Ph.D. dissertation, 151 p.

Smith, L.M., Pederson, R.L., and Kaminski, R.M., eds., Habitat management for migrating and wintering waterfowl in North America: Lubbock, Tex., Texas Tech University Press, 560 p.

Stewart, R.E., and Kantrud, H.A., 1974, Breeding waterfowl conditions in the prairie pothole region of North Dakota: Condor, v. 76 , p. $70-79$.

Swanson, G.A., 1988, Aquatic habitats of breeding waterfowl, in Hook, D.D., McKee, W.H., Jr., Smith, H.K., and others, eds., The ecology and management of wetlands; v. I, The ecology of wetlands: Portland, Oreg., Timber Press, $592 \mathrm{p}$.

Swanson, G.A., and Duebbert, H.F., 1989, Wetland habitats of waterfowl in the prairie pothole region, in Valk, A.G., van der, ed., Northern prairie wetlands: U.S. Fish and Wildlife Service National Wetlands Inventory, p. 228-267.

Tiner, R.W., 1984, Wetlands of the United States-current status and recent trends: Washington, D.C., U.S. Fish and Wildlife Service Report, 59 p.

Trauger, D.L., and Stoudt, J.H., 1978, Trends in waterfowl populations and habitats on study are as in Canadian parklands: North American Wildlife and Natural Resources Conference Transactions, v. 43, p. 187-205.

U.S. Fish and Wildlife Service, 1993, Annual report of lands under control of the U.S. Fish and Wildlife Service as of September 30, 1993: Washington, D.C., U.S. Fish and Wildlife Service Division of Realty, $43 \mathrm{p}$.

in press, Wetlands of international importance-United States participation in the "Ramsar" Convention, $11 \mathrm{p}$.

Van Rees-Siewert, K.L., 1993, The influence of wetland age on bird and aquatic macroinvertebrate use of restored Iowa wetlands: Ames, Iowa, Iowa State University of Science and Technology, M.S. thesis, $96 \mathrm{p}$.

Weigert, R.G., and Freeman, B.J., 1990, Tidal salt marshes of the southeastern Atlantic Coast-a community profile: U.S. Fish and Wildlife Service Biological Report 85(7.29), 82 p.

Weller, M.W., 1990, Waterfowl management techniques for wetland enhancement, restoration and creation useful in mitigation procedures, in Kusler, J.A., and Kentula, M.E., eds., Wetland creation and restoration-the status of the science: Washington, D.C., Island Press, p. 517-528.

Winkler, Jacqueline, 1987, Federal regulations and agency policies for waterfowl projects in coastal wetlands, in Whitman, W.R., and Meredith, W.H., eds., Symposium on Waterfowl and Wetlands Management, Proceedings: Dover, Del., Delaware Division of Fish and Wildlife Coastal Management Program, p. 500-504.

Wetland Protection Legislation

Clean Water Act, 1978, Public Law 95-217, Section 404: U.S. Code, v. 33, sec. 1344.

Conservation Foundation, 1988, Protecting America's wetlands- an action agenda: Washington, D.C., The Conservation Foundation, $15 \mathrm{p}$.

Council of Environmental Quality, 1989, Environmental trends: Washington, D.C., Council of Environmental Quality, Office of the President, $152 \mathrm{p}$.

Cowardin, L.M., Carter, Virginia, Golet, F.C., and LaRoe, E.T., 1979, Classification of wetlands and deepwater habitats of the United States: U.S. Fish and Wildlife Service, Biological Sciences Program Report, FWS/OBS-79/31, 131 p.

Dahl, T.E., 1990, Wetlands-losses in the United States 1780's to 1980's: Washington, D.C., U.S. Fish and Wildlife Service Report to Congress, $13 \mathrm{p}$.

Davis, M.L., and Gardner, R.C., 1993, Recognizing the Corps' commitment: National Wetlands Newsletter, v. 15, no. 2, p. 9.

Dennison, M.S., and Berry, J.F., 1993, Wetlands-guide to science, law, and technology: Park Ridge, N.J., Noyes Publications, $439 \mathrm{p}$.

Environmental Law Institute, 1980, Bottomland hardwoodstheir functions, values, and status: National Wetlands Newsletter , v. 2, no. 1, p. 6-8.

Environmental Law Reporter, 1992a, Agencies working to resolve controversy, official says: Washington, D.C., Bureau of National Affairs, v. 23, no. 13, p. 924.

1992b, Reilly favors return to 1987 manual, cites emerging consensus on delineation: Washington, D.C., Bureau of National Affairs, v. 23, no. 17, p. 1260.

Executive Order 11988, 1977, Floodplain management: Issued on May 24, 1977, by the President.

Executive Order 11990, 1977, Protection of wetlands: Issued on. May 24, 1977, by the President.

Federal Water Pollution Control Act, 1972, Public Law 92-500, Section 404: U.S. Code, v. 33, sec. 1344.

Hightower, Mike, and Calnan, Thomas, 1993, The functions and values of coastal wetlands: Austin, Tex., Texas General Land Office, $145 \mathrm{p}$.

Holmes, B.H., 1972, A history of Federal water resources programs, 1800-1960: U.S. Department of Agriculture, Miscellaneous Publication 1233, $51 \mathrm{p}$.

Kadlec, R.H., and Bevis, F.B., 1990, Wetlands and wastewater: Wetlands, v. 10, no. 1, p. 77-92.

Kentula, M.E., Brooks, R.P., Gwin, S.E., Holland, C.C., and Sherman, A.D., 1992, An approach to improving decision making in wetland restoration and creation: U.S. Environmental Protection Agency, EPA/600/R-92/150, 151 p.

Lewis, Roy, 1992, Why Florida needs mitigation banking: National Wetlands Newsletter, v. 14, no. 1, p. 7.

Maurizi, Susan, and Poillon, Florence, eds., 1992, Restoration of aquatic ecosystems-science, technology, and public policy: Washington, D.C., National Research Council, 552 p.

Mitsch, W.J., and Gosselink, J.G., 1993, Wetlands (2d ed.): New York, Van Nostrand Reinhold 722 p.

Morris, Marya, 1991, Wetland protection-a local government handbook: Chicago, Ill., American Planning Association, 31 p.

National Environmental Policy Act of 1969, 1976, Section 102: U.S. Code, v. 42, sec. 4332.

North Carolina v. Tullock, 1992, Civ. No. C90-713-CIV-3-BO (E.D.N.C., Feb. 24, 1992).

Office of Technology Assessment, 1984, Wetlands-their use and regulation: Washington, D.C., U.S. Congress, OTA-0-206, $208 \mathrm{p}$.

Redmond, Ann, 1992, How successful is mitigation?: Washington, D.C., National Wetlands Newsletter, v. 14, no. 1, p. 5-6.

Schley, Terry, and Winter, Linda, 1992, New 404(q) MOA-diluting EPA's role: Washington, D.C., National Wetlands 
Newsletter, v. 14 , no. 6 , p. 8.

Scodari, P.F., 1990, Wetlands protection-the role of economics: Washington, D.C., Environmental Law Institute, 89 p.

Tietenberg, Tom, 1992, Environmental and natural resource economics: New York, Harper Collins, 678 p.

Tiner, R.W., 1984, Wetlands of the United States-current status and recent trends: Washington, D.C., U.S. Fish and Wildlife Service Report, $59 \mathrm{p}$.

Turner, Kerry, and Jones, Tom, eds., 1990, Wetlands-market and intervention failures, four case studies: London, Earthscan Publications, $192 \mathrm{p}$.

U.S. Army Corps of Engineers, 1987, Corps of Engineers wetlands delineation manual: Washington, D.C., Department of the Army, U.S. Army Corps of Engineers Technical Report Y-87-1.

1994, An examination of wetlands programs-opportunities for compensatory mitigation: Bethesda, M.D., IWR Report 94-WMB-5, $96 \mathrm{p}$.

1994, National wetland mitigation banking study-wetland mitigation banking: Washington, D.C., Environmental Law Institute IWR Report 94-WMB-6, 178 p.

U.S. Department of the Interior, 1988, The impact of Federal programs on wetlands, v. I of A report to Congress by the Secretary of the Interior: Washington, D.C, October, 1988, 114 p.

1994, The impact of Federal programs on wetlands, v. II of A report to Congress by the Secretary of the Interior: Washington, D.C., 333 p.

U.S. Environmental Protection Agency, 1988, Environmental progress and challenges-EPA's update: U.S. Environmental Protection Agency, EPA-230-07-88-033, 140 p.

1991, Proposed revisions to the Federal manual for delineating wetlands: Washington, D.C., U.S. Environmental Protection Agency, Office of Wetlands, Oceans, and Watersheds, p. 1-4.

1995, Wetlands fact sheet 4 -economic benefits of wetlands: U.S. Environmental Protection Agency, EPA843-F95-001d.

U.S. Fish and Wildlife Service, 1984, Digest of Federal resource laws of interest to the U.S. Fish and Wildlife Service: Washington, D.C., U.S. Fish and Wildlife Service, Office of Legislative Services, $26 \mathrm{p}$.

U.S. General Accounting Office, 1988, Wetlands-the Corps of Engineers' administration of the Section 404 program: Washington, D.C., U.S. General Accounting Office GAO/RCED88-110, $122 \mathrm{p}$.

Want, William, 1993, Law of wetlands regulation: Deerfield, Ill., Clark Boardman Callaghan, p. 13-2.

Watzin, M.C., 1990, Coastal barrier resources system mapping process, in Federal coastal wetland mapping program: U.S Fish and Wildlife Service Biological Report 90(18), p. 21-26.

White House Office of Environmental Policy, 1993, Protecting America's wetlands-a fair, flexible, and effective approach: Washington, D.C., U.S. Government Printing Office, 26 p.

Whitehead, J.C., 1990, Measuring willingness-to-pay for wetlands preservation with the contingent valuation method: Wetlands, v. 10, no. 2, p. 187-202.

World Wildlife Fund, 1992, Statewide wetlands strategies-a guide to protecting and managing the resource: Washington, D.C., Island Press, 268 p.

\section{Wetland Research by Federal Agencies}

Cowardin, L.M., Carter, Virginia, Golet, F.C., and LaRoe, E.T., 1979, Classification of wetlands and deepwater habitats of the United States: U.S. Fish and Wildlife Service, Office of Biological Services Report FWS/OBS-79/31, 131 p.
Frayer, W.E., Monahan, T.J., Bowden, D.C., and Graybill, F.A., 1983, Status and trends of wetlands and deepwater habitats in the conterminous United States, 1950's to 1970's: Fort Collins, Colo., Colorado State University, 32 p.

U.S. Army Corps of Engineers, Institute for Water Resources, 1994, National wetland mitigation banking study - an examination of wetlands programs-opportunities for compensatory mitigation: Bethesda, M.D., IWR Report 94-WMB-5, 96 p.

U.S. Army Corps of Engineers, 1992, National summary of ongoing wetlands research by Federal agencies : Vicksburg, Miss., U.S. Army Corps of Engineers Waterways Experiment Station, Wetlands Research Program, 69 p.

Wetlands Research Subcommittee, 1992, Federal agency wetlands research-inventory and needs: an unpublished report through the Federal Coordinating Committee on Science, Engineering, and Technology to the Domestic Policy Council, $61 \mathrm{p}$.

White House Office of Environmental Policy, 1993, Protecting America's wetlands-a fair, flexible, and effective approach: Washington, D.C., U.S. Government Printing Office, 26 p.

Wetland Mapping and Inventory

Anderson, J.R., Hardy, E.E., Roach, J.T., and Witmer, R.E., 1976 $A$ land use and land cover classification system for use with remote sensor data: U.S. Geological Survey Professional Paper $964,28 \mathrm{p}$.

Cowardin, L.M., Carter, Virginia, Golet, F.C., and LaRoe, E.T., 1976, Interim classification of wetland and aquatic habitats of the United States, in Sather, J.H., ed., National wetland classification and inventory workshop, College Park , Md., 1975, Proceedings: U.S. Fish and Wildlife Service Report, 358 p.

1977, Classification of wetland and deepwater habitats of the United States: U.S. Fish and Wildlife Service Report, 100 p.

1979. Classification of wetlands and deepwater habitats of the United States: U.S. Fish and Wildlife Service, Office of Biological Services FWS/OBS-79/31, 103 p.

Dahl, T.E., 1990, Wetlands-losses in the United States, 1780's to 1980's: Washington, D.C., U.S. Fish and Wildlife Service Report to Congress, 13 p.

1991, Wetland resources of the United States: St. Petersburg, Fla., U.S. Fish and Wildlife Service Special Map, scale $1: 3,168,000$.

Emergency Wetlands Resources Act, 1986, Public Law 99-645.

Federal Interagency Committee for Wetland Delineation, 1989, Federal manual for identifying and delineating jurisdictional wetlands: U.S. Army Corps of Engineers, U.S. Environmental Protection Agency, U.S. Fish and Wildlife Service, and U.S. Soil Conservation Service, Cooperative technical publication, $76 \mathrm{p}$.

Frayer, W.E., Monahan, T.J., Bowden, D.C., and Graybill, F.A. 1983, Status and trends of wetlands and deepwater habitats in the conterminous United States, 1950's to 1970's: Fort Collins, Colo., Colorado State University, 32 p.

Hall, J.V., 1991, Wetland resources of Alaska: U.S. Fish and Wildlife Service Map, scale 1 inch equals 40 miles.

Kiraly, S.J., Cross, F.A., and Buffington, J.D., eds., 1990, Federal coastal wetland mapping programs: Springfield, Va., U.S. Fish and Wildlife Service Biological Report 90(18), 174 p.

National Audubon Society, 1993, Saving wetlands-a citizen's guide for action in the mid-Atlantic region: Camp Hill, $\mathrm{Pa}$., National Audubon Society, [130 p.].

Reed, P.B., Jr., 1988, National list of plant species that occur in wetlands-1988 national summary: U.S. Fish and Wildlife Service Biological Report 88(24), 244 p.

Shaw, S.P., and Fredine, C.G., 1956, Wetlands of the United States-their extent and their value to waterfowl and other 
wildlife: U.S. Fish and Wildlife Service Circular 39, 67 p.

Smith, G.S., 1991, NWI maps made easy-a user's guide to national wetlands inventory maps of the northeast region: U.S. Fish and Wildlife Service, $15 \mathrm{p}$.

Swartwout, D.J., MacConnel, W.P., and Finn, J.T., 1982, An evaluation of the National Wetlands Inventory in Massachusetts, in Brann, T.B., House, L.O., and Lund, H.G., In-Place Resource Inventories Workshop, Orono, Maine, 1981, Proceedings: Bethesda, Md., Society of American Foresters, 7 p.

Teels, B.M., 1990, Soil Conservation Service's wetland inventory: U.S. Fish and Wildlife Service Biological Report 90(18), $11 \mathrm{p}$.

U.S. Domestic Policy Council, 1990, Report of the wetland inventory subgroup of the Domestic Policy Council Interagency Wetlands Task Force: Executive Office of the President, $22 \mathrm{p}$.

U.S. Fish and Wildlife Service, 1976, Existing State and local wetland surveys (1965-1975); v. II, Narrative: U.S. Fish and Wildlife Service, Office of Biological Services Report, 453 p.

1986, North American waterfowl management plan-a strategy for cooperation: U.S. Fish and Wildlife Service and Canada Wildlife Service, $37 \mathrm{p}$.

U.S. Soil Conservation Service, 1987, Hydric soils of the United States: Washington, D.C., U.S. Soil Conservation Service Miscellaneous Publication 1491, unnumbered pages.

Wilen, B.O., and Pywell, H.R., 1992, Remote sensing of the Nation's wetlands, National Wetlands Inventory: Forest Service Remote Sensing Applications Conference, 4th biennial, Orlando, Fla., 1992, Proceedings, unnumbered pages.

Wilen, B.O., and Tiner, R.W., 1993, Wetlands of the United States, in Whigham, D.F., Dykyjová, Dagmar, and Hejny, Slavomil, eds., Wetlands of the world I-inventory, ecology, and management: Dordrecht, The Netherlands, Kluwer Academic Publishers, p. 515-636.

World Wildlife Fund, 1992, Statewide wetlands strategies-a guide to protecting and managing the resource: Washington, D.C., Island Press, 268 p.

\section{Wetland Functions, Values, and Assessment}

Adamus, P.R., 1983, Method for wetland functional assessment; v. 2, FHWA Assessment method: Federal Highway Administration Report FHWA-IP-82-24, 134 p.

1988, The FHWA/Adamus (WET) method for wetland functional assessment., in Hook, D.D., McKee, W.H., Jr., Smith, H.K., and others, eds., The ecology and management of wetlands; v. 2, Management, use, and value of wetlands: Portland, Oreg., Timber Press, p. 128-133.

1992, Review of sources and methods, in World Wildlife Fund, Statewide wetlands strategies-a guide to protecting and managing the resource: Washington, D.C., Island Press, p. $171-224$.

Adamus, P.R., Clairain, E.J., Jr., Smith, R.D., and Young, R.E., 1987, Wetland Evaluation Technique (WET): Vicksburg, Miss., U.S. Army Corps of Engineers, Waterways Experiment Station, Operational Draft Technical Report, v. 2, 206 p. plus appendixes.

Adamus, P.R., and Stockwell, L.T., 1983, Critical review and evaluation concepts, v. 1 of Method for wetland functional assessment: Federal Highway Administration Report FHWAIP-82-23, $176 \mathrm{p}$.

Bedford, B.L., and Preston, E.M., eds., 1988, Cumulative effects on landscape systems of wetlands-scientific status, prospects, and regulatory perspectives: Environmental Management, v. 12 , no. 5 , p. 565-775.
Brinson, M.M., 1993, Hydrogeomorphic classification for wetlands: Washington, D.C., U.S. Army Corps of Engineers, Wetlands Research Program Technical Report WRP-DE-4, $79 \mathrm{p}$.

Dahl, T.E., and Johnson, C.E., 1991, Wetlands—-status and trends of wetlands and deepwater habitats in the conterminous United States, mid-1970's to mid-1980's: Washington, D.C., U.S. Fish and Wildlife Service, 22 p.

Frayer, W.E., Monahan, T.J., Bowden, D.C., and Graybill, F.A., 1983 , Status and trends of wetlands and deepwater habitats of the conterminous United States, 1950's to 1970's: Fort Collins, Colo., Colorado State University, 32 p.

Greeson, P.E., Clark, J.R., and Clark, J.E., eds., 1979, Wetland functions and values-the state of our understanding: $\mathrm{Na}$ tional Symposium on Wetlands, Lake Buena Vista, Fla., 1978, Proceedings: Minneapolis, Minn., American Water Resources Association, $674 \mathrm{p}$.

Helfgott, T.B., Lefor, M.W., and Kennard, W.C., 1973, Wetlands Conference, 1st: Storrs, Conn., 1973, Proceedings: Storrs, Conn., University of Connecticut, Institute of Water Resources, Report 21, 199 p.

Karr, J.R., and Dudley, D.R., 1981, Ecological perspective on water quality goals: Environmental Management, v. 5, p. 55-68.

Karr, J.R., Fausch, K.D., Angermeier, P.L., Yant, P.R., and Schlosser, I.J., 1986, Assessing biological integrity in running waters-a method and its rationale: Champaign, Ill., Illinois Natural History Survey Special Publication 5, 28 p.

Kusler, J.A., 1980, Regulating sensitive lands-a guidebook: Cambridge, Mass., Ballinger Publishing Co., 248 p.

1983 , Our national wetland heritage - a protection guidebook for local government: Washington, D.C., Environmental Law Institute, p 4.

Kusler, J.A., and Kentula, M.E., 1989a, Wetland creation and restoration-the status of the science; v. 1, Regional reviews: Corvallis, Oreg., U.S. Environmental Protection Agency, Environmental Research Laboratory, EPA/600/3-89/038A, 473 p.

$1989 \mathrm{~b}$, Wetland creation and restoration-the status of the science; v. 2, Perspectives: Corvallis, Oreg., U.S. Environmental Protection Agency, Environmental Research Laboratory, EPA/600/3-89/038B, 179 p.

Kusler, J.A., and Montanari, J.H., 1978, National Wetland Protection Symposium: U.S. Fish and Wildlife Service, Office of Biological Services, FWS/OBS-78-97, Proceedings, 255 p.

Kusler, J.A., Quammen, M.J., and Brooks, Gail, eds., 1988, National Wetland Symposium-Mitigation of Impacts and Losses, Proceedings: New Berne, N.Y., Association of State Wetland Managers, Inc., Technical Report 3, 446 p.

Kusler, J.A., and Riexinger, Patricia, eds., 1986, National Wetland Assessment Symposium, Proceedings: Association of State Wetland Managers, Inc., Albany, N.Y., 331 p.

Lapedes, D.N., ed., 1976, McGraw Hill dictionary of scientific and technical terms: New York, McGraw Hill, 1634 p.

Larson, J.S., ed., 1973, Models for evaluation of freshwater wetlands: Amherst, Mass., University of Massachusetts, Water Resources Research Center, Publication 32, Completion Report FY-76-5, $91 \mathrm{p}$.

Larson, J.S., and Neill, Christopher, eds., 1987, Mitigating freshwater wetland alterations in the glaciated northeastern United States-an assessment of the science base: Amherst, Mass., University of Massachusetts, The Environmental Institute, Publication 87-1, 143 p.

Leibowitz, S.G., Abbruzzese, Brooks, Adamus, P.R., Hughes, L.E., and Irish, J.T., 1992, A synoptic approach to cumulative impact assessment-a proposed methodology: Corvallis, Oreg., U.S. Environmental Protection Agency, Environmental 
Research Laboratory, EPA/600/P-92/167, 106 p.

Lonard, R.I., Clairain, E.J., Jr., Huffman, R.T., Hardy, J.W., Brown, L.D., Pallard, P.E., and Watts, J.W., 1981, Analysis of methodologies used for the assessment of wetland values-final report: Vicksburg, Miss., U.S. Army Corps of Engineers, Waterways Experiment Station, Environmental Laboratory, $80 \mathrm{p}$.

National Audubon Society, 1993, Saving wetlands-a citizen's guide for action in the mid-Atlantic region: Camp Hill, $\mathrm{Pa}$., National Audubon Society, [130 p.]

National Wetlands Policy Forum, 1988, Protecting America's wetlands-An action agenda: Washington, D.C., The Conservation Foundation, $69 \mathrm{p}$.

Neale, C.M.U., Hardy, T.B., and Shoemaker, J.A., 1994, Evaluation of coastal wetland states using spatial and spectral metrics derived from multispectral video imagery: Corvallis, Oreg., U.S. Environmental Protection Agency, Environmental Research Laboratory, $56 \mathrm{p}$.

Novitzki, R.P., 1979, Hydrologic characteristics of Wisconsin's wetlands and their influence on floods, stream flow, and sediment, in Greeson, P.E., Clark, J.R., and Clark, J.E., eds., Wetland functions and values-the state of our understanding: National Symposium on Wetlands, Lake Buena Vista, Fla., 1978, Proceedings: Minneapolis, Minn., American Water Resources Association, p. 377-388.

1994, EMAP-Wetlands-a program for assessing wetland condition, in Mitsch, W.J., ed., Global wetlands-old world and new: New York, Elsevier Science Publishers.

Novitzki, R.P., Rosen, B.H., McAllister, L.S., Ernst, T.L., Huntley, B.E., and Dwire, K., 1994, EMAP-Wetlands-research strategy for the assessment of wetland condition: Corvallis, Oreg., U.S. Environmental Protection Agency, Environmental Research Laboratory, $149 \mathrm{p}$.

Parrett, Charles, Melcher, N.B., and James, R.W., Jr., 1993, Flood discharges in the upper Mississippi River Basin, 1993: U.S. Geological Circular 1120-A, 14 p.

Patience, N., and Klemas, V.V., 1993, Wetland functional health assessment using remote sensing and other techniques-literature search: Beaufort, N.C., Southeast Fisheries Science Center, National Oceanic and Atmospheric Administration Technical Memorandum NMFS-SEFSC-319, 108 p.

Preston, E.M., and Bedford, B.L., 1988, Evaluating cumulative effects on wetland functions-a conceptual overview and generic framework, in Bedford, B.L., and Preston, E.M., eds., Cumulative effects on landscape systems of wetlands-scientific status, prospects, and regulatory perspectives: Environmental Management, v. 12, no. 5, p. 565-583.

Richardson, Brandt, ed., 1981, Midwest Conference on Wetland Values and Management, St. Paul, Minn., 1981, Selected Proceedings: St. Paul, Minn., Minnesota Water Planning Board, $660 \mathrm{p}$.

Rosenbaum, Nelson, 1979, Enforcing wetlands regulations, in Greeson, P.E., Clark, J.R., and Clark, J.E., eds., Wetland functions and values-the state of our understanding: $\mathrm{Na}$ tional Symposium on Wetlands, Lake Buena Vista, Fla., 1978, Proceedings: Minneapolis, Minn., American Water Resources Association, p. 43-49.

Sather, J.H., ed., 1976, National Wetland Classification and Inventory Workshop, College Park, Md., 1975, Proceedings: Washington, D.C., U.S. Fish and Wildlife Service, 110 p.

Smith, R.D., Ammann, Alan, Bartoldus, C., and Brinson, M.M., 1995, An approach for assessing wetland functions using hydrogeomorphic classification, reference wetlands, and functional indices: Vicksburg, Miss., U.S. Army Engineers Waterways Experiment Station, Technical Report TRWRPDE 10, [100 p.].
Tiner, R.W., 1989, Wetlands of Rhode Island: Newton Corner, Mass., U.S. Fish and Wildlife Service, National Wetlands Inventory, 71 p., appendix.

Turner, R.E., and Swenson, E.M., 1993, Indicator development for evaluating estuarine emergent condition-Salt marsh pilot study-technical narrative (draft final report): Baton Rouge, La., Louisiana State University, v. 1, 65 p.

U.S. Environmental Protection Agency, 1984, Literature review of wetland evaluation methodologies, technical report: Chicago, Ill., U.S. Environmental Protection Agency, Region 5, $117,13 \mathrm{p}$.

Wolf, R.B., Lee, L.C., and Sharitz, R.R., 1986, Wetland creation and restoration in the United States from 1970 to 1985: Society of Wetland Scientists, Wetlands, v. 6, p. 1-88.

\section{Wetland Restoration and Creation}

Brooks, R.P., 1993, Restoration and creation of wetlands, in Dennison, M.S., and Berry, J.F., eds., 1993, Wetlands: guide to science, law, and technology: Park Ridge, N.J., Noyes Publications, p. 319-351.

Brown, M.T., 1991, Evaluating constructed wetlands through comparisons with natural wetlands: Corvallis, Oreg., U.S. Environmental Protection Agency, Environmental Research Laboratory, EPA/600/3-91/058, 37 p.

Brown, M.T., Schaefer, Joseph, and Brandt, Karla, 1989, Buffer zones for water, wetlands, and wildlife in east central Florida: Gainesville, Fla., University of Florida, Center for Wetlands, Publication Number 89-07 and Florida Agricultural Experiment Station Journal Series Number T-00061, various pagings.

Chabreck, R.H., 1988, Coastal marshes-ecology and wildlife management: Minneapolis, Minn., University of Minnesota Press, $138 \mathrm{p}$.

Confer, S.R., and Niering, W.A., 1992, Comparison of created and natural freshwater emergent wetlands in Connecticut: Wetlands Ecology and Management, v. 2, no. 3, p. 143-156.

Frenkel, R.E., and Morlan, J.C., 1990, Restoration of the Salmon River salt marshes-retrospect and prospect: Corvallis, Oreg., Department of Geosciences, Oregon State University, U.S. Environmental Protection Agency, Region 10, 142 p.

1991, Can we restore our salt marshes? Lessons from the Salmon River, Oregon: Northwest Environmental Journal, v. 7, p. 119-135.

Galatowitsch, S.M., and Valk, A.G. van der, 1994, Restoring prairie wetlands-an ecological approach: Ames, Iowa, Iowa State University Press, 246 p.

Garbisch, E.W., Jr., 1986, Highways and wetlands-compensating wetland losses: Federal Highway Administration Report DOT-FH-11-9442, 60 p.

Gosselink, J.G., Lee, L.C., and Muir, T.A., eds., 1990, Ecological processes and cumulative impacts, illustrated by bottomland hardwood wetland ecosystems: Chelsea, Mich., Lewis Publishers, Inc., 708 p.

Gwin, S.E., and Kentula, M.E., 1990, Evaluating design and verifying compliance of wetlands created under Section 404 of the Clean Water Act in Oregon: Corvallis, Oreg., U.S. Environmental Protection Agency, Environmental Research Laboratory, EPA/600/3-90/061, 122 p.

Gwin, S.E., Kentula, M.E., and Frostholm, D.L., in conjunction with Tighe, R.L., 1991, Evaluating design and verifying compliance of created wetlands in the vicinity of Tampa, Florida: Corvallis, Oreg., U.S. Environmental Protection Agency, Environmental Research Laboratory, EPA/600/3-91/068, 107 p.

Hammer, D.A., ed., 1989, Constructed wetlands for wastewater 
treatment-municipal, industrial, and agricultural: Chelsea, Mich., Lewis Publishers, Inc., 831 p.

1992, Creating freshwater wetlands: Chelsea, Mich., Lewis Publishers, Inc., 298 p.

Hollands, G.G., 1990, Regional analysis of creation and restoration of kettle and pothole wetlands, in Kusler, J.A., and Kentula, M.E., eds., Wetland creation and restoration-the status of the science: Washington, D.C., Island Press, p. 281-298.

Hook, D.D., McKee, W.H., Jr., Smith, H.K., Gregory, J., Burrell, V.G., Jr., DeVoe, M.R., Sojka, R.E., Gilbert, S., Banks, R., Stolzy, L.H., Brooks, C., Matthews, T.D., and Shear, T.H., 1988; The ecology and management of wetlands; v. 2, Management, use, and value of wetlands: Portland, Oreg., Timber Press, $394 \mathrm{p}$.

Kentula, M.E., Brooks, R.P., Gwin, S.E., Holland, C.C., Sherman, A.D., and Sifneos, J.C., 1992, An approach to improving decision making in wetland restoration and creation: Washington, D.C., Island Press, 151 p.

King, D.M., 1991, Wetland creation and restoration-an integrated framework for evaluating costs, expected results and compensation ratios: Washington, D.C., U.S. Environmental Protection Agency, Office of Policy, Planning, and Evaluation, $79 \mathrm{p}$.

Kruczynski, W.L., 1990, Options to be considered in preparation and evaluation of mitigation plans, in Kusler, J.A., and Kentula, M.E., eds., Wetland creation and restoration-the status of the science: Washington, D.C., Island Press, p. 555-570.

Kusler, J.A., and Daly, Sally, eds., 1989, International Symposium on Wetlands and River Corridor Management, Charleston, S.C., 1989, Proceedings: Berne, N.Y., Association of State Wetland Managers, $520 \mathrm{p}$.

Kusler, J.A., and Kentula, M.E., 1990a, Executive summary, in Kusler, J.A., and Kentula, M.E., eds., Wetland creation and restoration-the status of the science: Washington, D.C., Island Press, p. xvii-xxv.

$1990 \mathrm{~b}$, Wetland creation and restoration-the status of the science: Washington, D.C., Island Press, 591 p.

Langis, Rene, Zalejko, M.K., and Zedler, J.B., 1991, Nitrogen assessments in a constructed and natural salt marsh of San Diego Bay: Ecological Applications, v. 1, p. 40-51.

Leibowitz, S.G., Preston, E.M., Arnaut, L.Y., Detenbeck, N.E., Hagley, C.A., Kentula, M.E., Olson, R.K., Sanville, W.D., and Sumner, R.R., 1992, Wetland research plan-an integrated risk-based approach: Corvallis, Oreg., U.S. Environmental Protection Agency, Environmental Research Laboratory, EPA/600/R-92/060, 123 p.

Lewis, R.R., Jr., 1990, Wetland restoration/creation/enhancement terminology - suggestions for standardization, in Kusler, J.A., and Kentula, M.E., eds., Wetland creation and restoration-The status of the science: Washington, D.C., Island Press, p. $417-423$.

Lugo, A.E., S.L., and Brinson, M.M., eds., 1990, Forested wetlands-ecosystems of the world, 15: Amsterdam, The Netherlands, Elsevier Science Publishers, 527 p.

Majumdar, S.K., Brooks, R.P., Brenner, F.J., and Tiner, R.W., Jr., eds., 1989, Wetlands ecology and conservation-emphasis in Pennsylvania: Philadelphia, Pa., Pennsylvania Academy of Science, $395 \mathrm{p}$.

Marble, A.D., 1990, A guide to wetland functional design: Federal Highway Administration Report FHWA-IP-90-010, 222 p.

Maynord, S.T., Landin, M.C., McCormick, J.W., Davis, J.E., Evans, R.A., and Hayes, D.F., 1992, Design of habitat restoration using dredged material at Bodkin Island, Chesapeake Bay, Maryland: U.S. Army Corps of Engineers, Wetlands Research Program Technical Report WRP-RE-3, 33 p. plus tables and figures.

Millar, C.I., and Libby, W.J., 1989, Restoration-Disneyland or a native ecosystem? A question of genetics: Restoration and Management Notes, v. 7, p. 18-23.

Mitsch, W.J., and Gosselink, J.G., 1993, Wetlands (2d ed.): New York, Van Nostrand Reinhold, 722 p.

Mitsch, W.J., Straskraba, Milan, and Jorgensen, S.E., eds., 1988, Wetland modelling: New York, Elsevier Science Publishers, $227 \mathrm{p}$.

National Research Council Committee on Restoration of Aquatic Ecosystems, 1992, Restoration of aquatic ecosystems-science, technology, and public policy: Washington, D.C., National Academy Press, $552 \mathrm{p}$.

Niering, W.A., 1989, Effects of storm water runoff on wetland vegetation, Stormwater Conference, Southborough, Mass., Proceedings: New England Institute for Environmental Studies, p. 1-38.

O'Brien, A.L., 1986, Hydrology and the construction of a mitigating wetland, in Larson, J.S., and Neill, Christopher, eds., Mitigating freshwater wetland alteration in the glaciated northeastern United States - an assessment of the science base: Amherst, Mass., University of Massachusetts, The Environmental Institute, Publication 87-1, 143 p.

Olson, R.K., ed., 1992, Special issue-the role of created and natural wetlands in controlling nonpoint source pollution: Ecological Engineering, v. 1, p. 1-170.

Pacific Estuarine Research Laboratory, 1990, A manual for assessing restored and natural coastal wetlands with examples from southern California: LaJolla, Calif., California Sea Grant Report T-CSGCP-021, 105 p.

Reed, P.B., Jr., 1988, National list of plant species that occur in wetlands-Northwest (Region 9): U.S. Fish and Wildlife Service Biological Report 88(26.9), 244 p.

Roberts, Leslie, 1993, Wetlands trading is a losing game, say ecologists: Science, v. 260, no. 5116, p. 1890-1892.

Schneller-McDonald, Karen, Ischinger, L.S., and Auble, G.T., [1990], Wetland creation and restoration-description and summary of the literature: U.S. Fish and Wildlife Service Biological Report 90(3), 198 p., data base records.

Segelquist, C.A., Slauson, W.L., Scott, M.L., and Auble, G.T., 1990 , Synthesis of soil-plant correspondence data from twelve wetland studies throughout the United States: U.S. Fish and Wildlife Service Biological Report 90(19), 24 p.

Sharitz, R.R., and Gibbons, J.W., eds., 1989, Freshwater wetlands and wildlife: Department of Energy Symposium Series 61, Charleston, S.C., 1986, Proceedings: U.S. Department of Energy CONF-8603101, 1265 p.

Simenstad, C.A., Tanner, C.D., Thom, R.M., and Conquest, L.D., 1991, Estuarine habitat assessment protocol: Seattle, Wash., U.S. Environmental Protection Agency, Region 10, EPA/910/ 9-91-037.

Stark, Nellie, 1972, Low maintenance vegetation-wildland shrubs, their biology and utilization, in International Shrub Symposium, Ogden, Utah, 1971, Proceedings: U.S. Forest Service General Technical Report INT-1, 494 p.

Thayer, G.W., ed., 1992, Restoring the Nation's marine environment: College Park, Md., Maryland Sea Grant College, 716 p.

Thornburg, A., 1977, Use of vegetation for stabilization of shorelines of the Great Lakes: Workshop on the role of vegetation in stabilization of the Great Lakes shoreline, Proceedings: Ann Arbor, Mich., Great Lakes Basin Commission, p. 39-53.

Tiner, R.W., 1995, Wetland protection and creation, in Nierenberg, W.A., ed., 1995, Encyclopedia of environmental biology: San Diego, Calif., Academic Press, v. 3, p. 517-534. U.S. Army Corps of Engineers, 1992, National summary of on- 
going wetlands research by Federal agencies: Vicksburg, Miss., U.S. Army Corps of Engineers, Waterways Experiment Station, Wetlands Research Program, 69 p.

U.S. Soil Conservation Service, 1991, Hydric soils of the United States: U.S. Soil Conservation Service Miscellaneous Publication 1491, unnumbered pages.

1992, Field handbook, chapter 13: Wetland restoration, enhancement, and creation: Washington, D.C., U.S. Soil Conservation Service, $79 \mathrm{p}$.

Valk, A.G. van der, ed., 1989, Chemical characteristics of water in Northern prairie wetlands: U.S. Fish and Wildlife Service National Wetlands Inventory, p. 57-90.

Valk, A.G. van der, and Davis, C.B., 1976, The seed banks of prairie glacial marshes: Canadian Journal of Botany, v. 54, p. 1832-1838.

Weinhold, C.E., and Valk, A.G. van der, 1988, The impact of duration of drainage on the seed banks of northern prairie wetlands: Canadian Journal of Botany, v. 67, p. 1878-1884.

Wenzel, T.A., 1992, Minnesota wetland restoration guide: Minneapolis, Minn., Minnesota Board of Water and Soil Resources, [variably numbered].

White, T.A., Lea, R., Haynes, R.J., Nutter, W.L., Nawrot, J.R., Brinson, M.M., and Clewell, A.F., 1990, Development and summary of MiST: a classification system for preproject mitigation sites and criteria for determining successful replication of forested wetlands, in Skousen, Jeff, Sencindiver, John, and Samuel, Dave, eds., Mining and Reclamation Conference and Exhibition, Charleston, W. Va., 1990, Proceedings: American Society of Surface Mining and Reclamation, p. 323-325.

Zedler, J.B., 1993, Canopy architecture of natural and planted cordgrass marshes - selecting habitat evaluation criteria: Ecological Applications, v. 3, p. 123-138.

Zedler, J.B., and Kentula, M.E., 1986, Wetlands research plan: Corvallis, Oreg., U.S. Environmental Protection Agency, Environmental Research Laboratory, EPA/600/3-86/009, 118 p.

\section{Effects of Hurricane Andrew (1992) on Wetlands} in Southern Florida and Louisiana

Advocate, 1992, Hurricane damage numbers skyrocket: Baton Rouge, La., Advocate, September 2, sec. B, p. 3.

Alper, Joe, 1992, Everglades rebound from Andrew: Science, v. 257 , p. $1852-1854$.

Chabreck, R.H., and Linscombe, Greg, 1978, Vegetative type map of the Louisiana coastal marshes: New Orleans, La., Louisiana Department of Wildlife and Fisheries, 1 sheet.

Davis, G.E., Loope, L.L., Roman, C.T., Smith, G., and Tilmont, J.T., compilers, 1994, Assessment of Hurricane Andrew impacts on natural and archeological resources of Big Cypress National Preserve, Biscayne National Park, and Everglades National Park, 15-24 September 1992: National Park Service, $158 \mathrm{p}$.

Dunbar, J.B., Britsch, L.D., and Kemp, E.B., III, 1992, Land loss rates, report 3, Louisiana coastal plain: U.S. Army Corps of Engineers Technical Report GL-90-2, p. 27.
Federal Emergency Management Agency, 1992, Interagency hazard mitigation team report in response to the August 24, 1992, disaster declaration for the State of Florida, Hurricane Andrew: Federal Emergency Management Agency, FEMA 955-DR-FL, $178 \mathrm{p}$.

Fields, Gary, 1993, After Andrew, Louisiana's losses sink in: USA Today, January 8, 1993, sec. A, p. 10.

Gore, Rick, 1993, Andrew aftermath: National Geographic, v. 183 , no. 4 , p. 2-37.

National Oceanic and Atmospheric Administration, 1992, Special climate summary, Hurricane Andrew: Columbia, S.C., National Oceanic and Atmospheric Administration, Southeast Regional Climate Center, 7 p.

Rappaport, Edward, 1992, Preliminary report, Hurricane Andrew, 16-28 August 1992: Coral Gables, Fla., National Oceanic and Atmospheric Administration, National Weather Service, National Hurricane Center, $28 \mathrm{p}$.

Williams, S.J., Penland, Shea, and Roberts, H.H., 1993, Processes affecting coastal wetland loss in the Louisiana deltaic plain, in Magoon, O.T., Wilson, W.S., Converse, Hugh, and Tobin, L.T., eds., Coastal Zone '93-Symposium on Coastal and Ocean Management, 8th, New Orleans, La., 1993, Proceedings: New York, American Society of Civil Engineers, v. 1, p. 211-219.

\section{Effects of the Great Midwest Flood of 1993 on}

Wetlands

Interagency Floodplain Management Review Committee, 1994, Report to the administration floodplain management task force, sharing the challenge-science for floodplain management into the 21 st century: Washington, D.C., Interagency Floodplain Management Review Committee, $272 \mathrm{p}$.

Kusler, J.A., ed., 1993, Postflood recovery and the restoration of the Mississippi basin floodplain, including riparian habitat and wetlands-background materials for conference, September 28-29, 1993: Association of State Wetland Managers.

National Weather Service, 1994, The Great Flood of 1993: Washington, D.C., National Oceanic and Atmospheric Administration, Natural disaster survey report, $281 \mathrm{p}$.

National Weather Service, 1993, Update on Midwestern floodsheat and drought in the East: Special Climate Summary, v. 93.

Parrett, Charles, Melcher, N.B., and James, R.W., Jr., 1993, Flood discharges in the upper Mississippi River basin, in Floods in the upper Mississippi River basin, 1993: U.S. Geological Survey Circular 1120-A, 14 p.

Scientific Assessment and Strategy Team, 1994, Science for floodplain management into the 21 st century, draft report: Preliminary report to the Interagency Floodplain Management Review Committee of the Administration Floodplain Management Task Force.

Wahl, K.L., Vining, K.C., and Wiche, G.J., 1993, Precipitation in the upper Mississippi River basin, January 1 through July 31, 1993, in Floods in the upper Mississippi River basin, 1993: U.S. Geological Survey Circular 1120-B, 13 p. 